\title{
Motoneurons Derived from Induced Pluripotent Stem Cells Develop Mature Phenotypes Typical of Endogenous Spinal Motoneurons
}

\author{
Jeremy S. Toma, ${ }^{1}$ Basavaraj C. Shettar, ${ }^{1}$ Peter H. Chipman, ${ }^{1}$ Devanand M. Pinto, ${ }^{8}$ Joanna P. Borowska, ${ }^{1}$ \\ Justin K. Ichida, ${ }^{5}$ James P. Fawcett, ${ }^{3,4}$ Ying Zhang, ${ }^{1}$ Kevin Eggan, ${ }^{5,6,7}$ and Victor F. Rafuse ${ }^{1,2}$ \\ ${ }^{1}$ Department of Medical Neuroscience, ${ }^{2}$ Department of Medicine (Neurology), ${ }^{3}$ Department of Pharmacology, and ${ }^{4}$ Department of Surgery, Dalhousie \\ University, Halifax, Nova Scotia, Canada, B3H 4R2, ${ }^{5}$ Howard Hughes Medical Institute, ${ }^{6}$ Harvard Stem Cell Institute, Department of Stem Cell and \\ Regenerative Biology, and ${ }^{7}$ Department of Molecular and Cellular Biology, Harvard University, Cambridge, Massachusetts 02138, and ${ }^{8}$ National Research \\ Council, Institute for Marine Biosciences, Nova Scotia, Canada B3H 3Z1
}

Induced pluripotent cell-derived motoneurons (iPSCMNs) are sought for use in cell replacement therapies and treatment strategies for motoneuron diseases such as amyotrophic lateral sclerosis (ALS). However, much remains unknown about the physiological properties of iPSCMNs and how they compare with endogenous spinal motoneurons or embryonic stem cell-derived motoneurons (ESCMNs). In the present study, we first used a proteomic approach and compared protein expression profiles between iPSCMNs and ESCMNs to show that $<4 \%$ of the proteins identified were differentially regulated. Like ESCs, we found that mouse iPSCs treated with retinoic acid and a smoothened agonist differentiated into motoneurons expressing the LIM homeodomain protein Lhx3. When transplanted into the neural tube of developing chick embryos, iPSCMNs selectively targeted muscles normally innervated by Lhx3 motoneurons. In vitro studies showed that iPSCMNs form anatomically mature and functional neuromuscular junctions (NMJs) when cocultured with chick myofibers for several weeks. Electrophysiologically, iPSCMNs developed passive membrane and firing characteristic typical of postnatal motoneurons after several weeks in culture. Finally, iPSCMNs grafted into transected mouse tibial nerve projected axons to denervated gastrocnemius muscle fibers, where they formed functional NMJs, restored contractile force. and attenuated denervation atrophy. Together, iPSCMNs possess many of the same cellular and physiological characteristics as ESCMNs and endogenous spinal motoneurons. These results further justify using iPSCMNs as a source of motoneurons for cell replacement therapies and to study motoneuron diseases such as ALS.

Key words: electrophysiology; iPS cells; motoneuron disease; motoneurons; proteomics; stem cells

\section{Introduction}

Induced pluripotent stem cell-derived motoneurons (iPSCMNs) are being explored as a means to study motoneuron diseases and to develop therapeutics to treat amyotrophic lateral sclerosis (ALS; Dimos et al., 2008; Bilican et al., 2012; Burkhardt et al.,

Received May 21, 2014; revised Nov. 25, 2014; accepted Dec. 3, 2014.

Author contributions: V.F.R., J.S.T., B.C.S., P.H.C., J.P.F., Y.Z., and K.E. designed research; V.F.R., J.S.T., B.C.S., D.M.P., and J.P.B. performed research; J.K.I. and K.E. contributed unpublished reagents/analytic tools; V.F.R., J.S.T., B.C.S., D.M.P., J.P.B., J.K.I., J.P.F., Y.Z., and K.E. analyzed data; V.F.R., J.S.T., and Y.Z. wrote the paper.

This work was supported by the Canadian Institute of Health Research (to J.P.F., V.F.R., Y.Z.), the National Sciences and Engineering Research Council of Canada (to J.P.F., V.F.R.), and ALS Canada (Bernice Ramsay Innovation Grant from ALS Canada to V.F.R.). J.S.T. was supported by a scholarship from National Sciences and Engineering Research Council of Canada. We thank Cindee Leopold for stem cell culture maintenance, Matthew Mackenzie and Caitlin Jackson-Tarlton for myotube preparation, Cheryl Rafuse for FACS analysis, Kenneth Chisholm for proteomics sample preparation, and Andrew Leslie for analysis of proteomics data. The SV2, mab35, Lhx1, and Lhx3 monoclonal antibodies were obtained from the Developmental Studies Hybridoma Bank, created by the National Institute of Child Health and Human Development of the National Institutes of Health, and maintained at The University of lowa, Department of Biology, lowa City, lowa.

The authors declare no competing financial interests.

Correspondence should be addressed to Victor F. Rafuse, PhD, Department of Medical Neuroscience, Dalhousie University, 5859 College Street, P.0. Box 15000, Halifax, N.S., Canada B3H 4R2. E-mail: vrafuse@dal.ca.

DOI:10.1523/JNEUROSCI.2126-14.2015

Copyright $\odot 2015$ the authors $\quad 0270-6474 / 15 / 351291-16 \$ 15.00 / 0$
2013; Yao et al., 2013) and spinal muscular atrophy (Corti et al., 2012). Preclinical studies are proceeding using iPSCMNs harboring genetic mutations causing ALS to screen for small molecules promoting motoneuron survival and function (Egawa et al., 2012; Yang et al., 2013). Although it is hopeful that this approach will yield novel findings, its success is highly dependent on the supposition that iPSCMNs possess the same cellular and physiological traits as their endogenous counterparts. This assumption, however, has not been examined rigorously.

Embryonic stem cell-derived motoneurons (ESCMNs), on the other hand, have been shown to be remarkably similar to their endogenous counterparts (Chipman et al., 2012; reviewed by López-González and Velasco, 2012). ESCMNs develop mature electrophysiological firing properties and acquire the same passive membrane properties as spinal motoneurons (Miles et al., 2004). ESCMNs project axons to muscles lining the vertebral column when transplanted into the neural tube of chick embryos because they express the LIM homeodomain factor conferring medial motor column identity (Wichterle et al., 2002; Soundararajan et al., 2006; Soundararajan et al., 2007; Soundararajan et al., 2010). ESCMNs form functional and remarkably mature neuro- 

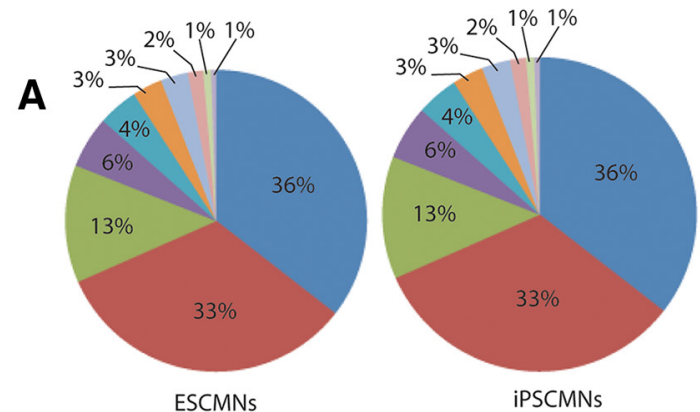

B
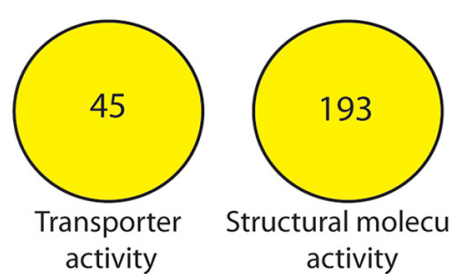

Structural molecule activity

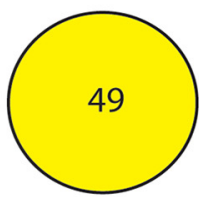

Translation

regulator

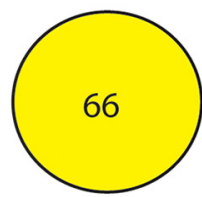

Enzyme

activity

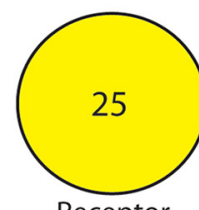

Receptor

activity

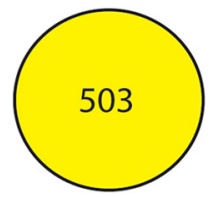

Catalytic

activity

\section{GO Ontology}

binding (GO:0005488)

catalytic activity (GO:0003824)

structural molecule activity (GO:0005198)

nucleic acid binding transcription factor (GO:0001071)

enzyme regulator activity (GO:00030234)

translation regulator activity (GO:0045182)

transporter activity (GO:0005215)

receptor activity (GO:0004872)

protein binding transcription factor activity (GO:0000988)

antioxidant activity (GO:0016209)
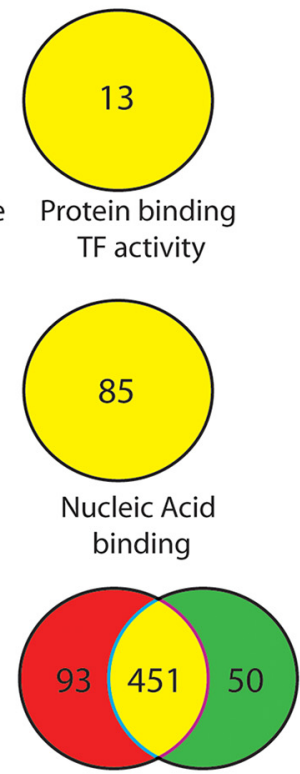

Binding

\section{C}

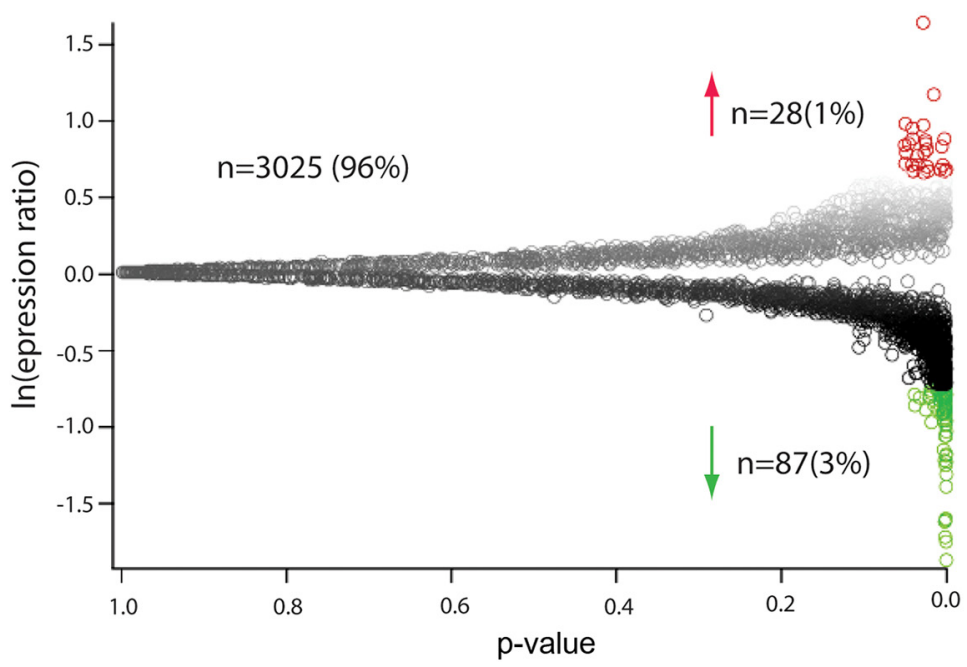

Figure 1. Proteomic analysis of iPSCMNs and ESCMNs. A, Proteins identified in the proteomic screen from the ESCMNs and iPSCMNs were assigned a G0 term using Panther classification (http://www.pantherdb.org/). The percentages of proteins matching to a G0 term from either the ESCMNs or iPSCMNs were then plotted. $\boldsymbol{B}$, The numbers of proteins identified that mapped to a defined G0 term from either the ESCMNs (red) or iPSCMNs (green) or both (yellow) were compared. C, Volcano plot of all data, consisting of 3025 unique, low-variability peptides. Each data point represents a protein identified by mass spectrometry. The natural log of the ratio of expression in iPSCMNs divided by the expression in ESCMNs is plotted against the $p$-value.

muscular junctions (NMJs) when cocultured with muscle fibers for several weeks (Chipman et al., 2014). Finally, ESCMNs restore contractile force to denervated muscles by forming functional NMJs with denervated myofibers when transplanted into the distal stump of a transected peripheral nerve (Yohn et al., 2008) in a manner analogous to embryonic motoneurons
(Thomas et al., 2000). Therefore, ESCMNs develop the same cellular, behavioral, and physiological characteristics as their endogenous counterparts and they are the same traits desired for iPSCMNs.

In this study, we compared mouse iPSCMNs with mouse ESCMNs to determine whether they possess the same develop- 
Table 1. Proteins up-regulated in iPSCMNs compared with ESCMNs (with an expression ratio > 2.00)

\begin{tabular}{|c|c|c|c|}
\hline Protein ID & Protein name & Ratio & G0 term \\
\hline G5E8H3 & DNA binding protein Ikaros & 5.37 & No hit \\
\hline P09041 & Phosphoglycerate kinase 2 & 3.35 & Catalytic activity \\
\hline Q6ZPI3 & Ligand dependent corepressor & 2.77 & Binding and catalytic activity \\
\hline Q2TPA8 & Hydroxysteroid dehydrogenase like protein 2 & 2.75 & Catalytic activity \\
\hline P52927 & High mobility group protein HMGI-C & 2.69 & Binding activity \\
\hline Q6PAL8 & DENN domain-containing protein $5 \mathrm{~A}$ & 2.51 & Transporter activity \\
\hline Q9QUG2 & DNA polymerase kappa & 2.51 & Binding and catalytic activity \\
\hline Q62470 & Integrin alpha 3 & 2.48 & No hit \\
\hline F2Z4B7 & Protein Raph1 & 2.44 & No hit \\
\hline Q60953 & Protein PML & 2.44 & No hit \\
\hline E9PY58 & Caseinolytic peptidase B protein homolog & 2.41 & No hit \\
\hline P70278 & Stimulated by retinoic acid gene 8 protein & 2.39 & No hit \\
\hline E909J4 & Inositol hexakisphosphate and diphosphoinositol-pentakisphosphate kinase 2 & 2.34 & No hit \\
\hline E9QN98 & Inactive dipeptidyl peptidase 10 & 2.29 & Catalytic activity \\
\hline Q9CR58 & Kidney mitochondrial carrier protein 1 & 2.29 & Binding and transporter activity \\
\hline Q8COE3 & Tripartite motif containing protein 47 & 2.25 & No hit \\
\hline Q9QUG9 & RAS guanyl-releasing protein 2 & 2.14 & Binding and catalytic activity and enzyme regulator activity \\
\hline A2RT91 & Ankyrin and armadillo repeat-containing protein & 2.12 & No hit \\
\hline F6TMC0 & Protein 9930021J03Rik & 2.12 & No hit \\
\hline Q8K0F1 & TBC1 domain family member 23 & 2.12 & No hit \\
\hline Q9ET80 & Junctophilin 1 & 2.10 & No hit \\
\hline S4R2F7 & RNA binding protein 25 & 2.05 & No hit \\
\hline E9PYH2 & Cytosolic acyl coenzyme A thioester hydrolase & 2.05 & No hit \\
\hline Q3V3R4 & Integrin alpha-1 & 2.03 & No hit \\
\hline P00405 & Cytochrome c oxidase subunit 2 & 2.03 & Catalytic activity \\
\hline E9QP35 & Protein 2310042D19Rik & 2.03 & Catalytic activity \\
\hline F7CHR4 & Inositol oxygenase & 2.03 & No hit \\
\hline E9PXP1 & Protein Brpf1 & 2.01 & No hit \\
\hline
\end{tabular}

Ratio, Expression in iPSCMNs divided by the expression in ESCMNs; G0 term, gene ontology assigned using Panther (www.pantherdb.org).

mental and physiological characteristics. We began by comparing global protein expression profiles between iPSCMNs and ESCMNs and found that $<4 \%$ of the proteins were differentially regulated. These results indicate that iPSCMNs and ESCMNs are similar at the level of protein expression. We then went on to compare iPSCMNs systematically with known traits of ESCMNs and found that they were also very similar with respect to axon targeting, the development of passive and active firing properties, and their ability to form anatomically mature and functional NMJs with cocultured muscle fibers. Finally, iPSCMNs restored contractile force to denervated muscles to the same extent as ESCMNs when transplanted into transected peripheral nerves of mice. These findings support the hypothesis that iPSCMNs form functional motoneurons that are remarkably similar to both ESCMNs and endogenous motoneurons. These traits further validate their use for studying motoneuron diseases and for developing therapeutics aimed to treat them.

\section{Materials and Methods}

Culturing of iPSCs. Isolated mouse iPSC colonies (and ESC colonies for experiments using ESCMNs) containing enhanced green fluorescent protein (eGFP) under the $\mathrm{Hb} 9$ promoter were differentiated into motoneurons (iPSCMNs) as described previously for mouse HBG3 ESCs (Wichterle et al., 2002; Miles et al., 2004; Soundararajan et al., 2006; Chipman et al., 2014). For the proteomic analysis, $\mathrm{eGFP}^{+}$motoneurons derived from iPSCs were compared with $\mathrm{eGFP}^{+}$motoneurons derived from the mouse HBG3 ESC line (Wichterle et al., 2002) using the same differentiation protocol.

Culturing iPSCMNs and immunocytochemistry. iPSCMNs were dissociated using TrypLE (Invitrogen) and plated on Matrigel (BD Biosciences $)$-coated coverslips $(\sim 350,000$ cells/coverslip $)$ and grown for $24-48 \mathrm{~h}$ in DFK10 and fixed for $\sim 20 \mathrm{~min}$ in $3.7 \%$ formaldehyde. Cells were then immunostained for both Lhx1 [mouse monoclonal, 1:2, supernatant; Developmental Studies Hybridoma Bank (DSHB)] and Lhx3 (mouse monoclonal, 1:5, supernatant, DSHB) expression. Cells were incubated in primary antibody with $0.3 \%$ Triton X/PBS solution and goat serum for $1 \mathrm{~h}$. Cells then underwent a $1 \mathrm{~h}$ incubation with the following secondary antibodies in $0.3 \%$ Triton X/PBS solution: goat antimouse Cy3 (Jackson Immunoresearch Laboratories, 1:500) and goat anti-rabbit Alexa Fluor 488 (Invitrogen, 1:500) for $1 \mathrm{~h}$ at room temperature. For cell counts, all $\mathrm{Lhx} 3^{+} / \mathrm{GFP}^{+}$or $\mathrm{Lhx} 1^{+} / \mathrm{GFP}^{+}$cells in 4 fields of view per coverslip (at $20 \times$ ) were counted. Total cell numbers were as follows for 3 experiments: $\mathrm{Lhx}^{+} / \mathrm{GFP}^{+}$cells $=844, \mathrm{Lhx} 1^{+} / \mathrm{GFP}^{+}$ cells $=1008$ with mean cell counts of $281.3 \pm 131.9\left(\mathrm{Lhx}^{+} / \mathrm{GFP}^{+}\right.$, mean $\pm 1 \mathrm{SD})$, and $336 \pm 63.6\left(\mathrm{Lhx}^{+} / \mathrm{GFP}^{+}\right)$. Images were acquired on a laser scanning confocal microscope (Zeiss LSM 510) and contrast and brightness adjustments were made on Adobe Photoshop CS5 software.

Proteomic analysis of iPSCMNs and ESCMNs. After fluorescentactivated cell sorting to purify the eGFP ${ }^{+}$iPSCMNs and ESCMNs, cells were stored at $-80^{\circ} \mathrm{C}$ until processed. Samples were thawed and diluted in $500 \mu \mathrm{l}$ of $50 \mathrm{~mm}$ TEAB, $\mathrm{pH} 8$ (Sigma T7408) with protease inhibitor (Set III Calbiochem 539134). Cells were lysed cells by probe sonication, $3 \times 5$ s cycles at power setting 1 (Fisher sonic dismembrator model 100). An aliquot containing $50 \mu \mathrm{g}$ of protein from each sample was diluted to a final volume of $600 \mu \mathrm{l}$ in $50 \mathrm{~mm}$ TEAB containing $0.1 \%$ Rapigest surfactant (Waters 186001861) samples sonicated a further $3 \times 5$ s cycles to ensure dissolution. Samples were reduced with $5 \mathrm{~mm}$ DTT (Sigma D9163) at $60^{\circ} \mathrm{C}$ for $30 \mathrm{~min}$, alkylated with $15 \mathrm{~mm}$ iodoacetamide (Sigma I6125) for $30 \mathrm{~min}$ at room temp, and then digested with trypsin (Promega V5113) at a $50: 1$ protein to trypsin ratio overnight at $37^{\circ} \mathrm{C}$. Resulting peptides acidified to $\mathrm{pH}<3$ with TFA (Sigma 299537), filtered through $0.45 \mu \mathrm{m}$ filter to remove hydrolyzed Rapigest detergent, and desalted using SPE cartridges (Waters HLB 186000383). Samples resuspended in $50 \mu \mathrm{l}$ water with $3 \%$ acetonitrile $0.1 \%$ formic acid. Each sample was injected 6 times in random order using $1 \mu$ injection volume. Chromatographic separations were conducted using a Dionex Ultimate 3000RSLCnano system equipped with a $15 \mathrm{~cm} \times 100 \mu \mathrm{m}$ Onyx monolithic $\mathrm{C} 18$ column (Phenomenex CHO-7646). The separation was performed using the following gradient (A: $0.1 \%$ formic acid in water, $\mathrm{B}$ : 
Table 2. Proteins down-regulated in iPSCMNs compared with ESCMNs (with an expression ratio < - 2.00)

\begin{tabular}{|c|c|c|c|}
\hline Protein ID & Protein name & Ratio & G0 term \\
\hline E9PX29 & Sptbn4 & -6.23 & Binding and structural molecular activity \\
\hline Q3UVI3 & Tumor protein 63 & -5.53 & No hit \\
\hline Q9ZOR6 & Intersectin 2 & -5.37 & No hit \\
\hline P23780 & Beta galactosidase & -4.85 & Catalytic activity \\
\hline 008644 & Ephrin type B receptor 6 & -4.81 & No hit \\
\hline E9QM22 & WD repeat containing protein 64 & -4.76 & No hit \\
\hline P47226 & Testin & -3.86 & No hit \\
\hline Q9JJ00 & Phospholipid scramblase 1 & -3.56 & No hit \\
\hline D3YYI5 & Glyceraldehyde-3-phosphate dehydrogenase & -3.35 & Catalytic activity \\
\hline B7ZCC9 & Probable G-protein coupled receptor 112 & -3.29 & Receptor activity \\
\hline Q8CF02 & Protein FAM25C & -3.25 & No hit \\
\hline Q9D823 & $60 S$ ribosomal protein $\mathrm{L} 37$ & -3.16 & Binding and structural molecular activity \\
\hline Q6RHR9 & $\begin{array}{l}\text { Membrane associated guanylate kinase WW and PDZ domain } \\
\text { containing protein } 1\end{array}$ & -3.13 & Catalytic activity \\
\hline P97807-2 & Cytoplasmic Isoform of Fumarate hydratase, mitochondrial & -3.03 & Catalytic activity \\
\hline P28658 & Ataxin 10 & -2.77 & No hit \\
\hline Q92019 & WD repeat containing protein 7 & -2.77 & Binding and structural molecular activity and enzyme regulator activity \\
\hline P97807 & Fumarate hydratase mitochondrial & -2.69 & Catalytic activity \\
\hline P56960 & Exosome component 10 & -2.59 & Binding and catalytic activity \\
\hline Q6Р1J1 & Crmp1 protein & -2.56 & No hit \\
\hline 011136 & Xaa-Pro dipeptidase & -2.53 & Binding and catalytic activity and nucleic acid binding transcription factor activity \\
\hline E9QP15 & Sister chromatid cohesion protein PDS5 homolog A & -2.51 & Binding \\
\hline Q811D0-3 & Isoform 3 of Disks large homolog 1 & -2.51 & No hit \\
\hline P20060 & Beta-hexosaminidase subunit beta & -2.51 & Catalytic activity \\
\hline D3YU56 & Inner nuclear membrane protein Man1 & -2.46 & No hit \\
\hline Q9CWX2 & Complex I intermediate-associated protein 30 mitochondrial & -2.46 & No hit \\
\hline 070200 & Allograft inflammatory factor 1 & -2.41 & Binding \\
\hline Q8BK67 & Protein $\mathrm{RCC} 2$ & -2.38 & Binding and catalytic and enzyme regulator activity \\
\hline Q8BHL5 & Engulfment and cell motility protein 2 & -2.39 & Binding \\
\hline Q805Z6 & Nuclear RNA export factor 7 & -2.39 & Binding \\
\hline 035066 & Kinesin-like protein KIF3C & -2.36 & Catalytic activity and structural molecule activity \\
\hline P68040 & Guanine nucleotide-binding protein subunit beta-2-like 1 & -2.34 & No hit \\
\hline Q9ERGO & LIM domain and actin-binding protein 1 & -2.34 & $\begin{array}{l}\text { Binding and catalytic activity and nucleic acid binding transcription factor activity and } \\
\text { Structural molecule activity }\end{array}$ \\
\hline B1AR39 & Protein 2810408A11Rik & -2.34 & No hit \\
\hline E9QAF9 & Protein TANC1 & -2.32 & No hit \\
\hline Q9CR98 & Protein FAM136A & -2.32 & No hit \\
\hline G3UYY1 & Serine hydroxymethyltransferase (Fragment) & -2.32 & No hit \\
\hline Q63918 & Serum deprivation-response protein & -2.32 & Binding and nucleic acid binding transcription factor activity \\
\hline E9Q7C4 & Protein Prr14l & -2.29 & No hit \\
\hline Q9ROHO-2 & Isoform 2 of Peroxisomal acyl-coenzyme A oxidase 1 & -2.29 & Catalytic activity \\
\hline Q684R7-3 & Isoform 3 of FRAS1-related extracellular matrix protein 1 & -2.29 & Transporter activity \\
\hline Q9D7S7 & 605 ribosomal protein L22-like 1 & -2.27 & Binding and structural molecule activity \\
\hline Q8C561 & LMBR1 domain-containing protein 2 & -2.27 & No hit \\
\hline 061526 & Receptor tyrosine-protein kinase erbB-3 & -2.27 & No hit \\
\hline Е9РXК1 & Cone-rod homeobox protein & -2.27 & No hit \\
\hline E9PW52 & Protein Gm3149 & -2.25 & No hit \\
\hline Q9JIL4 & $\mathrm{Na}(+) / \mathrm{H}(+)$ exchange regulatory cofactor NHE_RF3 & -2.20 & No hit \\
\hline Q7TPD1 & F-box only protein 11 & -2.20 & No hit \\
\hline B1AVKO & Protein FAM161A & -2.20 & No hit \\
\hline Q56A10 & Zinc finger protein 608 & -2.20 & No hit \\
\hline P51125 & Calpastatin & -2.18 & No hit \\
\hline Q4KWH5 & 1-phosphatidylinositol 4-5-bisphosphate phosphodiesterase eta-1 & -2.18 & Binding and catalytic activity and enzyme regulator activity \\
\hline Q91X46 & Rho guanine nucleotide exchange factor 3 & -2.16 & Binding and catalytic activity and enzyme regulator activity \\
\hline Q9D8U8 & Sorting nexin-5 & -2.16 & No hit \\
\hline Q9D117 & MACRO domain containing 2 & -2.16 & No hit \\
\hline P28481-2 & Isoform 3 of Collagen alpha-1(II) chain & -2.16 & Receptor activity and structural molecule activity and receptor activity \\
\hline P48754 & Breast cancer type 1 susceptibility protein homolog & -2.16 & Catalytic activity \\
\hline Q9CWL8 & Beta-catenin-like protein 1 & -2.16 & No hit \\
\hline P09411 & Phosphoglycerate kinase 1 & -2.14 & Catalytic activity \\
\hline Q9EOS9-3 & Isoform 3 of Immunoglobulin superfamily DCC subclass member 4 & -2.14 & Catalytic activity and receptor activity \\
\hline Q9D0R2 & Threonine-tRNA ligase, cytoplasmic & -2.14 & Catalytic activity \\
\hline D3YU82 & Probable cation-transporting ATPase $13 \mathrm{~A} 5$ & -2.14 & No hit \\
\hline B2RXC5 & Zinc finger protein 382 & -2.12 & Binding and nucleic acid binding transcription factor activity \\
\hline
\end{tabular}


Table 2. Continued

\begin{tabular}{llll}
\hline Protein ID & Protein name & Ratio & G0 term \\
\hline E90NJ9 & Fibroblast growth factor receptor 3 & -2.12 & No hit \\
Q9JI16 & Alcohol dehydrogenase [NADP(+)] & -2.12 & Catalytic activity and transporter activity \\
Q9CZP7 & Hsp90 co-chaperone Cdc37-like 1 & -2.12 & Binding and catalytic activity and enzyme regulator activity \\
H3BJZ2 & Protein Cdhr4 & -2.12 & Binding and receptor activity \\
P53996 & Cellular nucleic acid-binding protein & -2.10 & Binding \\
Q80U87 & Ubiquitin carboxyl-terminal hydrolase 8 & -2.10 & Binding and catalytic activity \\
E901W0 & Calcium/calmodulin-dependent protein kinase type Il subunit beta & -2.10 & No hit \\
J30PC5 & Protein Zfp850 & -2.10 & No hit \\
P29391 & Ferritin light chain 1 & -2.08 & No hit \\
Q61771 & Kinesin-like protein KIF3B & -2.08 & Catalytic activity and structural molecule activity \\
089086 & Putative RNA-binding protein 3 & -2.08 & Binding and catalytic activity and structural molecule activity \\
Q80US4 & Actin-related protein 5 & -2.08 & Structural molecule activity \\
P53996-2 & Isoform 2 of Cellular nucleic acid-binding protein & -2.08 & Binding \\
Q64331 & Unconventional myosin-VI & -2.08 & No hit \\
061176 & Arginase-1 & -2.08 & Catalytic activity \\
P97313 & DNA-dependent protein kinase catalytic subunit & -2.03 & Binding and catalytic activity \\
08K3P5 & CCR4-NOT transcription complex subunit 6 & -2.03 & Binding and catalytic activity \\
008677 & Kininogen-1 & -2.03 & No hit \\
\hline
\end{tabular}

Ratio, Expression in iPSCMNs divided by the expression in ESCMNs; G0 term, gene ontology assigned using Panther (www.pantherdb.org).

$0.1 \%$ formic acid in acetonitrile) at $300 \mathrm{nl} / \mathrm{min}$. The chromatographic separation gradient protocol was as follows: 3 minutes $97 \%$ A, $3 \%$ B; 5 minutes $95 \%$ A, 5\% B; 90 minutes $70 \%$ A, 30\% B; 95 min 3\% A, $97 \%$ B; 97 minutes 3\% A, 97\% B; 100 min, $97 \%$ A, 3\% B; 120 minutes $97 \%$ A, $3 \% \mathrm{~B}$.

Mass spectra were acquired on a Thermo Orbitrap Velos Pro using Xcalibur software. Data were acquired using data-directed analysis in which the $m / z$ values of tryptic peptides were measured using an MS scan in FT-MS mode followed by MS/MS scans of the 10 most intense peaks using IT-MS mode.

Data analysis was conducted using Proteome Discoverer for protein identification and Sieve for chromatographic alignment, normalization, and peak integration. Data were then extracted from the Sieve $\mathrm{sdb}$ database files using a series of custom scritpts written in R. Protein ontologies were assigned using gene list analysis tools in PANTHER (www.pantherdb.org).

In ovo transplantation of iPSCMNs and immunohistochemistry. Transplants were grafted into male and female chick embryos as described previously (Soundararajan et al., 2006) in accordance with the guidelines of the Canadian Council on Animal Care and the Dalhousie University Committee on Laboratory Animals.

For immunohistochemical analyses, the following primary antibodies were used: rabbit anti-GFP (Millipore Bioscience Research Reagents, 1:1000), mouse anti-Tuj1 (Covance, 1:1000). Slides were incubated with primary antibodies in a solution of $0.3 \%$ Triton X/PBS with goat serum overnight. Slides were incubated with the following secondary antibodies in $0.3 \%$ Triton X/PBS solution: goat anti-mouse Cy3 (Jackson Immunoresearch Laboratories, 1:500) and goat anti-rabbit Alexa Fluor 488 (Invitrogen, 1:500) for $1 \mathrm{~h}$ at room temperature. Images were captured with a digital camera (C4742; Hamamatsu Photonics) in conjunction with digital imaging acquisition software (IPLab; Version 4.0; BD Biosciences).

Analyses of axonal projections from the chick spinal cord were performed as follows: using Neurolucida projections from three separate embryos, the width of a line drawn across the $\mathrm{eGFP}^{+}$fascicle projecting dorsally toward the epaxial muscles was compared with the width drawn across eEGFP $^{+}$fascicles projecting ventrally toward the limb. The crosssectional areas of the fascicles were then calculated (assuming a circular area, $\pi r^{2}$ ) and relative sizes compared.

iPSCMN/myofiber cocultures and immunocytochemistry. For generating myofibers, the medial head of the adductor superficialis muscles of Hamburger Hamilton (HH) St. 36 chicks were isolated and plated on 13 $\mathrm{mm}$ sterile thermanox plastic coverslips (Nunc) in 24-well plates as described previously before addition of iPSCMNs (Chipman et al., 2014). For immunohistochemical analysis of the cocultures, cells were incubated in a solution containing rabbit anti-GFP IgG (Millipore Bioscience
Research Reagents, 1:2000), mouse anti-SV2 (1:50, DSHB) primary antibodies and goat serum for $\sim 1 \mathrm{~h}$. Cells were then washed in PBS multiple times for 30 minutes before incubating in goat anti-rabbit Alexa Fluor 488 (Invitrogen, 1:500), goat anti-mouse Alex Fluor 647 (Invitrogen, 1:500), and tetramethylrhodamine-conjugated (TMR) $\alpha$-bungarotoxin (btx; Invitrogen, 1:500). All antibodies were in a $0.3 \%$ Triton X/PBS solution. Images were acquired on a laser scanning confocal microscope (Zeiss LSM 510 or 710) or with a digital camera (C4742; Hamamatsu Photonics). Intensity of SV2 immunoreactivity and acetylcholine receptor area (based on TMR $\alpha$-btx labeling) were quantified using IPLab software (version 4.0; BD Biosciences). For each measurement of intensity of SV2 immunoreactivity, background intensity was subtracted from the signal. Orthogonal images were rendered and edited with LSM imaging software (Zeiss) and further contrast and brightness adjustments were performed on Adobe Photoshop version CS5.

FM4-64FX dye loading and imaging. To assess vesicular cycling at NMJs, cocultures were incubated with $5 \mu \mathrm{M}$ FM4-64FX (hereafter referred to as FM4-64) and motor terminals of iPSCMNs were loaded by electrical stimulation. Experiments were then conducted as described previously (Chipman et al., 2014).

Intracellular recordings of iPSCMN-chick myofiber cocultures. Sharp electrode recording techniques were used to assess synaptic function at 12- to 27-d-old cocultured NMJs as described previously (Miles et al., 2004; Soundararajan et al., 2007; Chipman et al., 2014). All cells recorded from had resting membrane potentials that varied from $\sim-25$ to -65 $\mathrm{mV}$, values that were similar to those previously reported for postsynaptic membrane potentials of in vitro rat spinal cord-myotube coculture (Robbins and Yonezawa, 1971).

Whole-cell patch-clamp recordings of $i P S C M N s$. iPSCMNs on Matrigelcoated coverslips were continuously perfused in a recording chamber with oxygenated $\left(95 \% \mathrm{O}_{2}+5 \% \mathrm{CO}_{2}\right)$ Ringer's solution containing the following (in mM): $111 \mathrm{NaCl}, 3.08 \mathrm{KCl}, 11$ glucose, $25 \mathrm{NaHCO}_{3}, 1.25$ $\mathrm{MgSO}_{4}, 2.52 \mathrm{CaCl}_{2}$, and $1.18 \mathrm{mM} \mathrm{KH}_{2} \mathrm{PO}_{4}, \mathrm{pH}$ 7.4, at room temperature for $\sim 20$ minutes before recording to allow the cells to adjust to recording conditions. Perfusion continued throughout the recordings, in which a DAGE-MTI IR-1000 CCD camera connected to an Olympus BX51WI

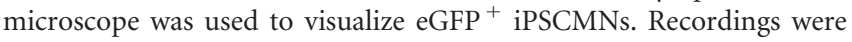
made in current-clamp mode using a MultiClamp 700B amplifier (Molecular Devices). A Digidata 1400A board (Molecular Devices) controlled by pCLAMP10.3 (Molecular Devices) was used to filter analog signals at $10 \mathrm{kHz}$. Recording solution containing the following (in $\mathrm{mM}$ ): 128 K-gluconate, $4 \mathrm{NaCl}, 0.0001 \mathrm{CaCl}_{2}, 10 \mathrm{HEPES}, 1$ glucose, $5 \mathrm{Mg}$-ATP, 0.3 GTP-Li, pH 7.2, was loaded into patch-clamp recording pipettes with a resistance of 4-7 M $\mathrm{M}$. Next, $0.4 \mathrm{mg} / \mathrm{ml}$ lucifer yellow dilithium salt (Sigma-Aldrich) was added to the pipette solution before recording to allow visualization of recorded iPSCMNs. To ensure similar measuring 

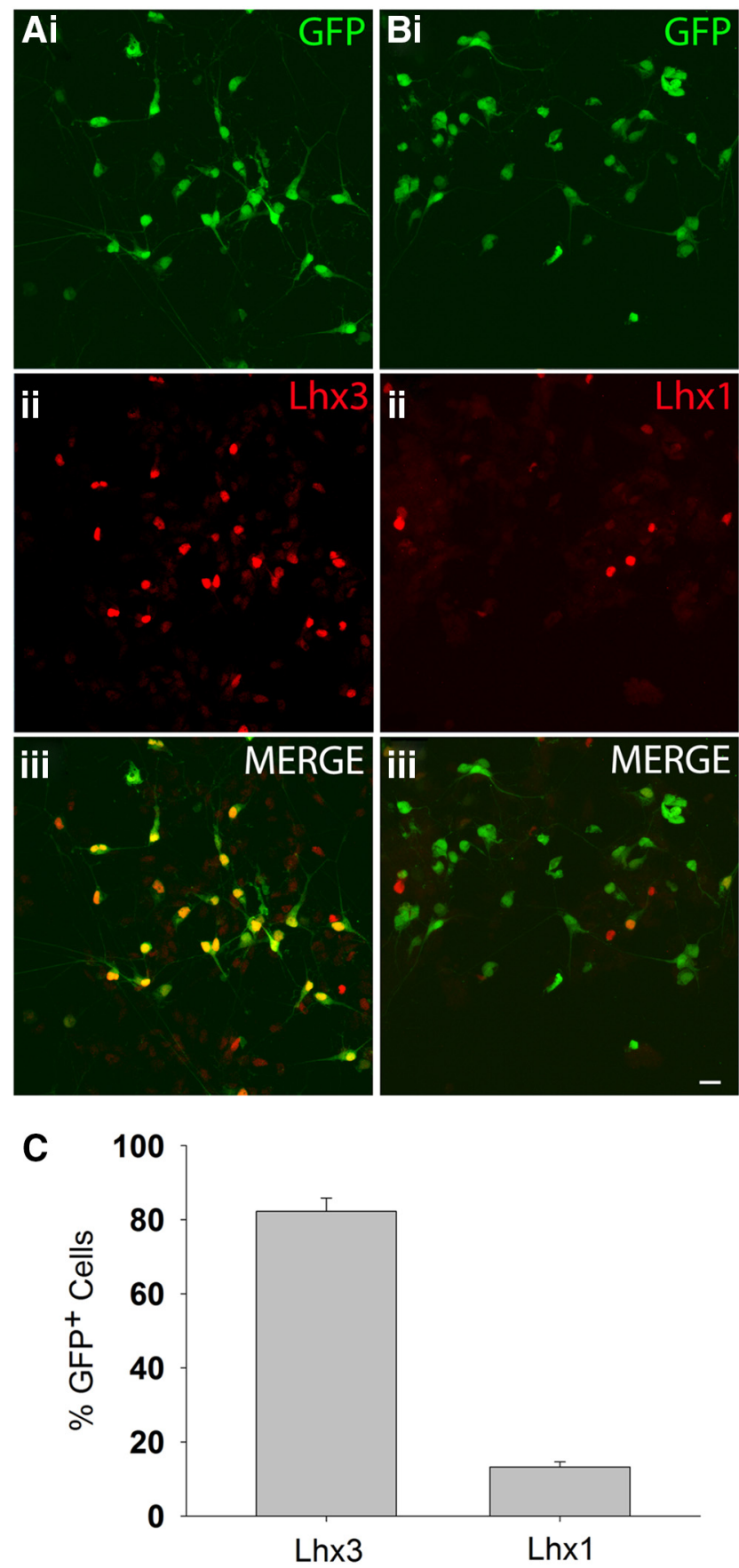

Figure 2. The vast majority of iPSCMNs express the LIM/homeobox protein Lhx3. Ai-Aiii, Immunolabeling showing that the majority of the eGFP ${ }^{+}{ }_{\mathrm{iPSCMN}}$ expressed Lhx3 after $2 \mathrm{~d}$ in vitro. Bi-Biii, In contrast, very few eGFP ${ }^{+}$iPSCMNs expressed Lhx1 after the same time period. C, Percentage of Lhx $3 /$ eGFP and Lhx $1 /$ eGFP $^{+}$cells after $2 \mathrm{~d}$ in vitro ( $n=3$ for each group). Scale bars, $10 \mu \mathrm{m}$.

conditions, all cells were held at $-60 \mathrm{mV}$ with a tonic DC current. Data were obtained by Clampex 10.3 (Molecular Devices) and analyzed by AxoScope 10.2 (Molecular Devices) software. Input resistance and capacitance of iPSCMNs were calculated by measuring response to repetitive, small negative steps of $-10 \mathrm{mV}$ for $100 \mathrm{~ms}$. For investigating firing properties of iPSCMNs, $1 \mathrm{~s}$ pulses of depolarizing current were delivered in increments of 5, 10, or $20 \mathrm{pA}$. Data were analyzed and statistics were generated with SigmaPlot 11 software (Systat Software).

iPSCMN implantation and force recording. All procedures performed were approved by the Dalhousie Animal Care Committee and complied with the Canadian Council of Animal Care. All surgeries were performed on male mice. The surgical technique used in this study has been described previously (Yohn et al., 2008). Immunohistochemistry performed on sections of nerve and muscle was conducted as described above for chick sections ( $1^{\circ}$ antibodies used: TMR $\alpha$-btx; Invitrogen), rabbit anti-GFP (Millipore Bioscience Research Reagents). Feret's diameter of MG muscles and muscle fibers was measured using Image J software.

Statistical analyses. All statistics were performed using SigmaPlot 11 Software (Systat). Values are cited as mean \pm 1 SD. All tests used are described in the text.

\section{Results \\ Protein expression is comparable between iPSCMNs and ESCMNs}

Throughout this study, we used a mouse iPSC line derived from transgenic mice (B6.Cg-Tg(Hlxb9-EGFP)1Tmj/J) expressing eGFP under the direction of the motoneuron-specific promoter Hb9 (Arber et al., 1999; Wichterle et al., 2002). Approximately $20 \%$ (mean: $21.3 \% \pm 3.09$ ) of the cells from this iPSC line differentiated into $\mathrm{GFP}^{+}$motoneurons when treated with retinoic acid (RA) and a smoothened agonist (SAG). This is not significantly $(p=0.162, n=3)$ different from the percentage of motoneurons derived from mouse HBG3 ESCs using the same differentiation protocol (mean: $17.5 \% \pm 2.29$ ). Therefore, the propensity for mouse iPSCs and ESCs to differentiate into motoneurons when treated with RA and SAG is the same.

To determine whether there are differences between motoneurons derived from HBG3 ESCs (ESCMNs) and iPSC-derived motoneurons (iPSCMNs), we first undertook an unbiased proteomic approach and compared protein expression profiles between iPSCMNs and ESCMNs. Here, ESCMNs and iPSCMNs were sorted by fluorescence-activated cell sorting after differentiation before proteomic analysis. After trypsin digestion of the proteins, we performed a label-free, LC-MS/MS analysis of the resulting peptides to compare expression profiles, as described in the $\mathrm{Ma}-$ terials and Methods section. Quantification was perfomed using peptide peak areas and peptides with good precision (relative SD $<30 \%$ ) were retained. These peptides were then filtered to eliminate peptides that match to multiple proteins. The unique peptides were then averaged to give overall expression levels for 3025 proteins. We next imported the dataset into Panther (www. pantherdb.org) to annote known gene ontology (GO) terms to determine whether there were overall differences in the types of proteins identified in our screen. More than half (1531) of the proteins in the dataset matched a GO term. The half that did not match were likely unstudied proteins with no known function. When the 1531 proteins were grouped into each GO term, we found that the number (shown as a percentage) of proteins within each group was identical (Fig. 1A). This indicates that the types of proteins identified by the screen were very similar in the two cell types. Further analysis showed that ESCMNs and iPSCMNs express the same proteins of each GO term except for the general binding category (Fig. $1 B$ ), in which $>500$ general binding proteins were the same in ESCMNs and iPSCMNs: 93 were unique to ESCMNs and 50 to iPSCMNs (Fig. 1B).

To determine whether the same proteins in ESCMNs and iPSCMNs are expressed at similar levels, we integrated the intensity of each peptide and then averaged the peptides for any given protein to provide a fold change, defined here as the protein expression from the iPSCMNs divided by the intensity in the ESCMNs. Based on the variability measured, a $p$-value was also calculated, as shown in Figure $1 C$. We detected 28 proteins upregulated in iPSCMNs and 87 downregulated proteins (Tables 1 , 2 , respectively). Therefore, of the original number of proteins 

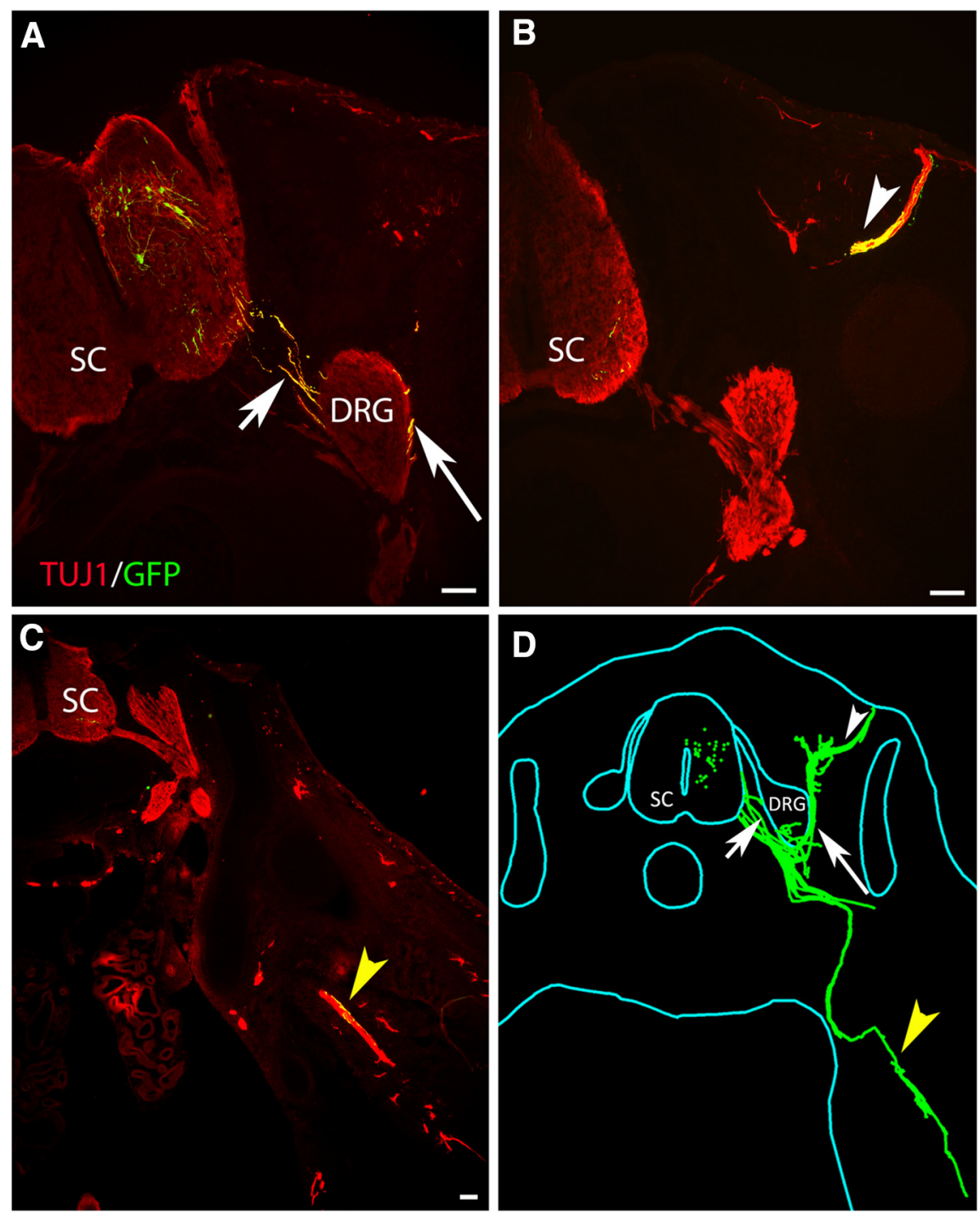

Figure 3. iPSCMNs preferentially project axons to epaxial muscles when transplanted in ovo. $\mathbf{A}-\mathbf{C}$, Cross-section through a $\mathrm{HH}$ St. 31 chick embryo showing eGFP ${ }^{+}$motor axons extended out of the spinal cord through the ventral root $(\boldsymbol{A}$, short arrow). The majority of the eGFP ${ }^{+}$axons extended around the DRG $\left(\boldsymbol{A}\right.$, arrow) and into epaxial muscles ( $\boldsymbol{B}$, white arrowhead). A few eGFP ${ }^{+}$ axons extended ventrally into the limb bud ( $\boldsymbol{C}$, yellow arrowhead). All sections were immunolabeled with Tuj1 to visualize the endogenous chick neurons (red) and transplanted eGFP ${ }^{+}$iPSCMNs (yellow). D, Neurolucida reconstruction of all cross-sections from one chick embryo receiving an iPSCMN transplant. eGFP ${ }^{+}$iPSCMNs are shown in green. Scale bar, $100 \mu \mathrm{m}$.

identified, $<4 \%$ met our criteria for being differentially regulated (i.e., a ln expression ratio $>0.7$ or $<-0.7$ in Fig. $1 C$ ). Interestingly, the degree of differential regulation was also modest, with the average fold change for the upregulated and downregulated proteins being 2.4 and -2.5 , respectively (Tables 1,2 ).

Finally, we focused on several transcription factors known to be involved in neuron and/or motoneuron differentiation (Alaynick et al., 2011; Son et al., 2011). Although we focused on a number of transcription factors, including Olig2, Nkx6.1, Nkx6.2, Ngn1, Ngn2, Lhx3, Hb9, Isl1, Isl2, Lmo4, Lhx1, FoxP1, Ascl1, Myt1l, and Brn2, we only detected Myt1l in our dataset. Nine unique peptides were identified for Mytl1, so it was conclusively identified. Myt1l was not differentially regulated between the two samples (ratio of $1.1, p$-value $=0.5$ ). Together, these results indicate that ESCMNs and iPSCMNs contain similar proteins at comparable levels of expression. The few proteins that were differentially expressed are not directly involved in motoneuron differentiation.
iPSCs preferentially differentiate into Lhx $3^{+}$motoneurons when treated with RA and SAG

Previous studies showed that mouse ESCs treated with SAG and RA preferentially differentiate into a specific subpopulation of motoneurons expressing the LIM homeoprotein Lhx3 (Soundararajan et al., 2006; Soundararajan et al., 2007; Soundararajan et al., 2010). Lhx3 ${ }^{+}$motoneurons reside in the medial aspect of the medial motor column and innervate epaxial muscles lining the vertebral column (Tsuchida et al., 1994). To determine whether iPSCs differentiate into the same motoneuron subset, we plated dissociated embryoid bodies containing $\mathrm{eGFP}^{+} \mathrm{iP}$ SCMNs onto a Matrigel substrate and cultured them for an additional $2 \mathrm{~d}$. The cells were then fixed and immunostained for LIM homeodomain proteins Lhx3 or Lhx1, the latter being a marker of motoneurons innervating the dorsal muscle mass in limbs (Tsuchida et al., 1994; Fig. $2 A, B)$. As observed with ESCMNs (Soundararajan et al., 2006; Soundararajan et al., 2007; Soundararajan et al., 2010), we found that the vast majority of

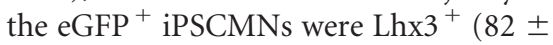
$3.7 \%, n=3$ ), whereas only $13 \pm 1.4 \%$ $(n=3)$ expressed Lhx1 (Fig. 2C). These results suggest that the process of motoneurogenesis using SAG and RA is similar between iPS and ESCs.

\section{iPSCMNs project axons to peripheral} targets appropriate for $\mathrm{Lhx} 3^{+}$ motoneurons when transplanted into the developing chick spinal cord

In the spinal cord, $\mathrm{Lhx}^{+}$motoneurons reside in the medial aspect of the medial motor column (Sharma et al., 1998). In the periphery, their axons selectively project to epaxial muscles lining the vertebral column (Tosney and Landmesser, 1985). This selective guidance of axons is orchestrated, at least in part, by intracellular signaling pathways that are activated downstream of Lhx3 expression (Sharma et al., 2000; Soundararajan et al., 2010). As a result, mouse $\mathrm{Lhx}^{+}{ }^{+}$ESCMNs selectively-and correctlyextend axons to epaxial muscles when transplanted into the neural tube of developing chick embryos at the time of motoneurogenesis (Soundararajan et al., 2006; Soundararajan et al., 2007; Soundararajan et al., 2010; i.e., HH St. 17). To determine whether similar guidance mechanisms direct the growth of axons from motoneurons derived from iPSCs, we transplanted eGFP ${ }^{+}$iPSCMNs into the neural tube of HH St. 17 chick embryos $(n=7)$. The embryos were killed $5 \mathrm{~d}$ later, fixed, sectioned, and processed for Tuj1 and eGFP immunohistochemistry to visualize chick and transplanted neurons, respectively. Figure 3 shows a representative pattern of axonal growth from one transplanted embryo. eGFP ${ }^{+}$axons extended out of the chick spinal cord via the ventral root (Fig. $3 A, D$, short arrow) around the dorsal root ganglia (DRG; Fig. $3 A, D$, arrow) to inner- 
vate epaxial muscles, the appropriate target for Lhx3 ${ }^{+}$motoneurons (Fig. $3 B, D$, white arrowhead). However, consistent with the transplants containing a small proportion of $\mathrm{Lhxl}^{+}$iPSCMNs (see above), a few eGFP ${ }^{+}$axons projected into the developing hindlimb bud (Fig. 3C,D, yellow arrowhead), an appropriate target for $\operatorname{Lhx} 1^{+}$motoneurons. To estimate the relative number of $\mathrm{eGFP}^{+}$axons projecting to the epaxial muscles and limb buds, we created Neurolucida reconstructions of the axonal projection patterns from each coronal section taken from three transplanted embryos. We then measured the width of the projections and found that $4.5 \pm 2.0$ times as many eGFP ${ }^{+}$axons projected to the epaxial muscles compared with the limb. This number is close to the expected distribution of axonal projections based on the relative number of $\mathrm{Lhx}^{+}$to $\mathrm{Lhx}^{+}$iPSCMNs in the transplants (i.e., the grafts contain $\sim 6.2$ times as many Lhx $3^{+}$motoneurons as $\mathrm{Lhx} 1^{+}$neurons; Fig. 2C). Therefore, the pattern of axonal growth accurately reflects the phenotypic identity of the transplanted iPSCMNs and that iPSCMNs use the same axonal guidance mechanisms as their endogenous $\mathrm{Lhx}^{+}$and $\mathrm{Lhx} 1^{+}$ counterparts.

\section{iPSCMNs form functional NMJs}

\section{in vitro}

Previous studies showed that ESCMNs form functional connections with muscle fibers in vitro (Miles et al., 2004; Soundararajan et al., 2007). To determine whether iPSCMNs have the same capacity, we first performed immunocytochemical analysis of presynaptic and postsynaptic structures associated with neurotransmission at the NMJ using cocultures containing eGFP ${ }^{+}$ iPSCMNs and chick myofibers (Miles et al., 2004). In the first week after plating, numerous $\mathrm{eGFP}^{+}$neurites were observed to extend radially from spherical clusters of iPSCMNs along individual chick myofibers (Fig. 4A). In addition, discrete, oval, plaque-like clusters of $\alpha$-btx ${ }^{+}$AChRs were observed around the neurites (Fig. $4 B-F)$. This pattern of clustering closely resembles normal in vivo development where AChRs first cluster near, but not always in direct contact with, innervating motor axons (Lupa and Hall, 1989; Dahm and Landmesser, 1991). The oval shape and sizes of the plaques $\left(41 \pm 24 \mu \mathrm{m}^{2}\right.$; $n=60,20$ plaques measured in each of 3 separate cocultures) were similar to AChR clusters found on developing muscles fibers in ovo during the first week of motoneuron innervation (i.e., E9; Phillips
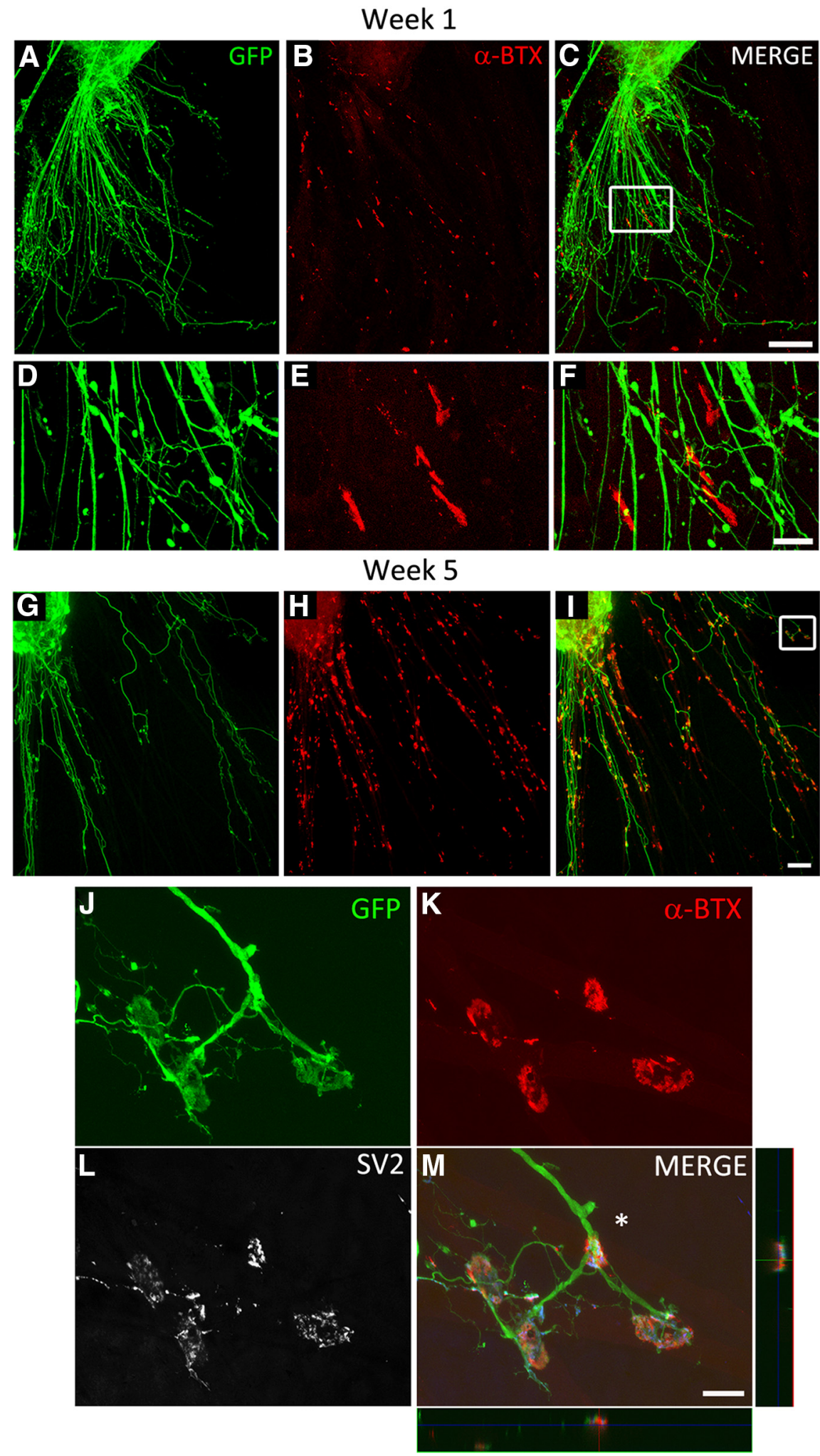

Figure 4. iPSCMNs form NMJs with cocultured chick myofibers. $\boldsymbol{A}-\boldsymbol{C}$, eGFP ${ }^{+}$motoneurons extend axons along myofibers $(\boldsymbol{A})$ and associate with plaques of $\alpha$-btx-labeled AChRs during the first week in culture $(\boldsymbol{B}, \boldsymbol{C}) . \boldsymbol{D}-\boldsymbol{F}$, Boxed area in $\boldsymbol{C}$ $\mathbf{G}-\mathbf{I}$, Contact between eGFP ${ }^{+}$axons and AChRs continues into week 5, when AChR clusters become much larger and maintained at myofiber regions in close proximity to eGFP ${ }^{+}$axons. $\boldsymbol{J}-\boldsymbol{L}$, Boxed area in $\boldsymbol{I}$ shows eGFP ${ }^{+}$axons $(\boldsymbol{J})$ contacting $\alpha$-btx labeled AChRs with pretzel-like morphologies $(\boldsymbol{K}) . \mathrm{SV}{ }^{+}$synaptic vesicles are prominent at the endplate in the presynaptic axon $(\boldsymbol{L})$. $\boldsymbol{M}$, Merged image of $\boldsymbol{J}-\boldsymbol{L}$ and $x-z$ and $y-z$ orthogonal planes of the NMJ indicated by the asterisk. Note the blue signal in the orthogonal planes and merge panel is SV2 labeling. Scale bars $C, I, 100 \mu \mathrm{m} ; \boldsymbol{F}, \boldsymbol{M}, 20$ $\mu \mathrm{m}$. 

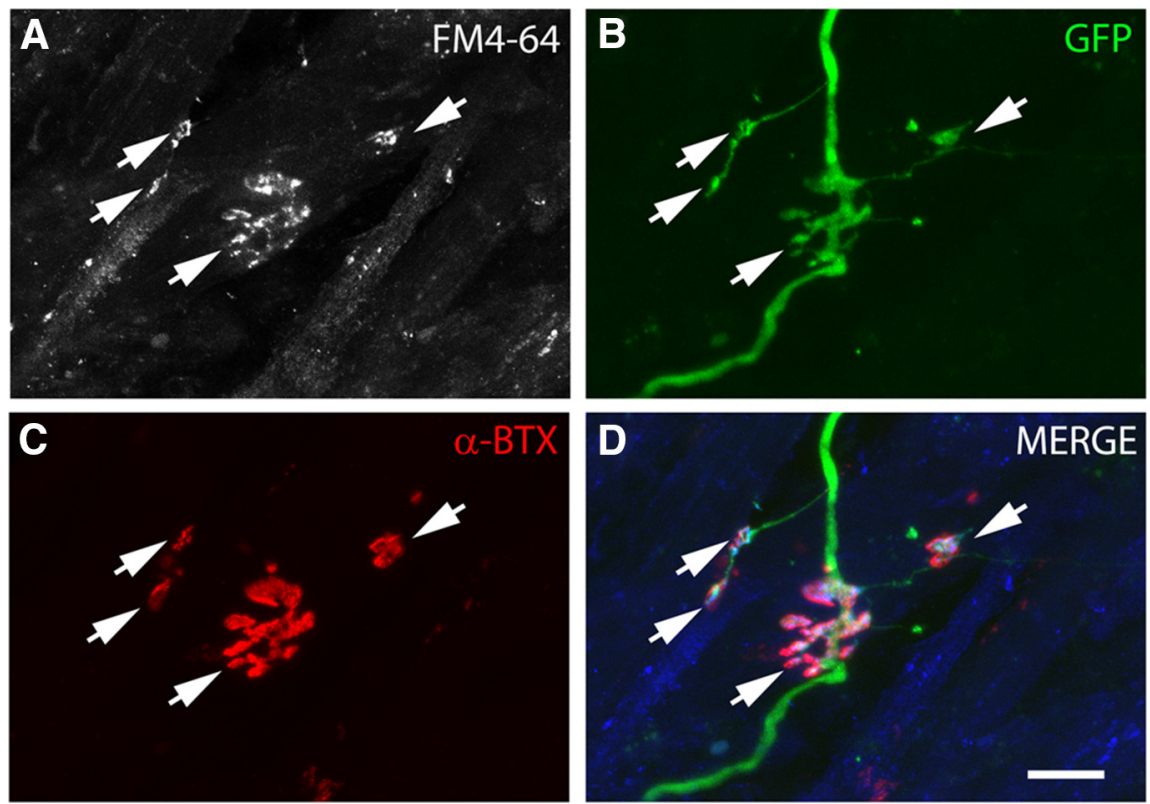

Figure 5. Active vesicular cycling occurs at NMJs formed between iPSCMNs and chick myofibers. $\boldsymbol{A}-\boldsymbol{C}$, FM4-64 puncta $(\boldsymbol{A})$ is present in eGFP ${ }^{+}$axons $(\boldsymbol{B})$ at endplates labeled with $\alpha$-btx $(\boldsymbol{C})$ after field electrical stimulation. $\boldsymbol{D}$, Merged image of $\boldsymbol{A}$ - $\boldsymbol{C}$ where the blue signal is FM4-64. Scale bar, $20 \mu \mathrm{m}$.

et al., 1985). iPSCMNs continued to maintain the eGFP ${ }^{+}$neurites after 4 weeks in vitro (Fig. $4 G$ ); however, at that point, the individual clusters of $\alpha$-btx ${ }^{+}$AChRs at the end of eGFP ${ }^{+}$ neurites formed structures resembling mature NMJs (Fig. $4 H, I)$. Higher magnification showed that $\alpha$-btx ${ }^{+}$AChR clusters were more complex, pretzel-shaped structures (Fig. $4 J, K)$. These endplates were also significantly larger than AChR clusters (plaques) present during the first week in culture (95 $\pm 37 \mu \mathrm{m}^{2}, n=60,20$ endplates measured in 3 separate cocultures, $p<0.001$, Mann-Whitney rank-sum test). This change in morphology is similar to what occurs in vivo as the NMJs mature postnatally (Slater, 1982; Balice-Gordon et al., 1993). By the fifth week in culture, $\mathrm{SV}_{2}{ }^{+}$puncta were enriched at the $\alpha$-btx ${ }^{+}$AChR rich endplates relative to the axonal shaft (Fig. $4 L, M$ ). Together, this suggests that the $\mathrm{eGFP}^{+}$neurites extend from the iPSCMNs and make appropriate synaptic connections with chick myotubes.

We next investigated whether synaptic vesicles actively cycle at the endplate to determine whether the NMJs were functional by incubating 4-week-old iPSCMN-myofiber cocultures with FM4-64 (Betz and Bewick, 1992; Gaffield and Betz, 2006). FM dyes are widely used to image synaptic vesicle cycling at the NMJ because the dye is readily taken up from the extracellular medium into endocytosed vesicles that have fused with the plasma membrane during nerve stimulation. Once the dye is trapped inside a vesicle, it can only escape from the NMJ by subsequent exocytosis of the vesicle (Gaffield and Betz, 2006). Consistent with the formation of functional synapses, we found that FM4-64 was readily taken up into cycling vesicles at presynaptic terminals using 50 $\mathrm{Hz}$ field electrical stimulation ( $1 \mathrm{~s}$ train of pulses, every $2 \mathrm{~s}$ for 5 minutes; Fig. 5A-D). As expected, the vast majority of the FM4-64 puncta (Fig. $5 A, D$ ) were adjacent to $\alpha$-btx ${ }^{+}$AChRs (Fig. 5C,D). We then performed intracellular sharp electrode recordings from NMJs labeled with a rhodamine-conjugated AChR antibody. Endplates chosen for recordings ( $n=22$; in 12- to 27 -d-old cocultures) had mature morphologies (i.e., pretzel-shaped distribution of AChRs) and were contacted by a single eGFP ${ }^{+}$axon (Fig. 6A,B).
The amplitude of the endplate potentials (EPPs) recorded varied between $\sim 0.5$ and $6 \mathrm{mV}$, which is comparable to those recorded from myofibers cocultured with embryonic rate spinal cord explants (Robbins and Yonezawa, 1971), a neuronal cell line (Chen et al., 2001), and ESCMNs (Miles et al., 2004). Figure 6C, top trace, shows 3 EPPs during a typical 5 s recording in normal solution; the bottom trace shows a similar recording in the presence of $100 \mu \mathrm{M}$ glutamate. The increased frequency and amplitude of the EPPs in the presence of glutamate indicates that, like ESCMNs (Miles et al., 2004) and endogenous motoneurons (Jiang et al., 1990), iPSCMNs express functional glutamatergic receptors. Bath application of $25 \mu \mathrm{M}$ TTX completely blocked the large EPPs $(>1.5 \mathrm{mV})$, but not the small EPPs (Fig. 6D). These results indicate that the smaller EPPs were miniature EPPs (mEPPs), whereas the larger EPPs resulted from evoked neurotransmitter release induced by action potentials in the motoneuron. As expected, all EPPs were blocked shortly after bath application of $100-300 \mu \mathrm{M}$ D-tubocurarine (Fig. $6 E ; n=3$ ), indicating that the EPPs were due to nicotinic neurotransmission. Together, these results indicate that iPSCMNs form functional NMJs similar to endogenous motoneurons and their ESCMN counterparts.

\section{iPSCMNs develop appropriate passive membrane and firing properties}

Motoneurons in the spinal cord undergo significant physiological changes during early postnatal development (Fulton and Walton, 1986; Gao and Ziskind-Conhaim, 1998; Nakanishi and Whelan, 2010). For example, input resistance decreases but whole-cell capacitance increases during the first 2 weeks of postnatal life. These changes in passive membrane properties reflect an overall increase in cell size and alteration in channel properties, both of which set the threshold for motoneuron excitability (Pinter et al., 1983; Fulton and Walton, 1986; Gao and ZiskindConhaim, 1998). Setting an appropriate threshold for activation is an essential feature of motoneurons because it ensures proper motoneuron recruitment and force gradation during muscle contraction.

To ascertain whether iPSCMNs develop appropriate passive membrane properties over time, we performed whole-cell patchclamp recordings on iPSCMNs cultured for 1-6 weeks on Matrigel-coated coverslips. We found that membrane input resistance $\left(R_{\mathrm{m}}\right)$ decreased between $1-2$ and 3-4 weeks (666 \pm 574 to $189 \pm 105 \mathrm{M} \Omega$; Table 3$)$. This decrease in resistance correlated well with the simultaneous increase in membrane capacitance $\left(C_{\mathrm{m}} ; 45 \pm 27 \mathrm{pF}\right.$ to $121 \pm 45$; Table 3$)$. These changes suggest that the average size and/or membrane area of the iPSCMNs increased over the first few weeks in culture, although significant size variations remained. The resting membrane potential of iPSCMNs, however, remained similar at all time points investigated (Table 3). These results are similar to those observed in cats and rats, in which input resistance decreases overtime (Fulton and Walton, 1986; Xie and Ziskind-Conhaim, 1995; Gao and Ziskind-Conhaim, 1998), whereas the resting membrane potential does not change between late embry- 
onic and early postnatal time periods (Xie and Ziskind-Conhaim, 1995).

The probability of generating repetitive action potentials in spinal motoneurons injected with a sustained depolarizing current increases between late embryogenesis and early postnatal life (Fulton and Walton, 1986; Gao and Ziskind-Conhaim, 1998). This change reflects maturation in channel properties over time. To determine whether channel properties in iPSCMNs mature over time, we applied stepwise injections of depolarizing current to iPSCMNs grown in culture for 1,2 , and 5 weeks. Figure 7 shows that iPSCMNs were able to generate repetitive action potentials at all three time points (Fig. $7 A$ ). However, the amount of current required to evoke repetitive action potentials decreased between 1 and 5 weeks (Fig. 7A). In addition, the maximum firing rate increased over time in culture (Fig. $7 A, C$ ) such that, by 5 weeks, the average frequency during the late phase of activity $(>250 \mathrm{~ms})$ was $41 \pm 10 \mathrm{~Hz}(n=3)$. This firing rate is comparable to the firing patterns of individual motor units in freely walking rats (Hennig and Lømo, 1985). Finally, the discharge rate of the evoked action potentials decreased overtime during the sustained injection of depolarizing current at all three time points (Fig. 7A,B). This phenomenon, known as spike-frequency adaptation, is a typical firing pattern of spinal motoneurons (Granit et al., 1963; Kernell and Monster, 1982).

Action potential duration decreases in motoneurons between late embryonic to early postnatal life (Gao and ZiskindConhaim, 1998). The same was true for cultured iPSCMNs (Fig. 8A,B), in which action potential duration (measured at half-maximal peak amplitude in sweeps in which a single spike was generated) was found to decrease from $5.9 \pm 1.6 \mathrm{~ms}$ $(n=11)$ at $1-2$ weeks to $2.29 \pm 0.43 \mathrm{~ms}$ ( $n=10$ ) by $5-6$ weeks. Furthermore, like embryonic rat motoneurons (Gao and Ziskind-Conhaim, 1998), only a minority $(38 \%, n=13)$ of the recorded iPSCMNs elicited an afterhyperpolarizing potential (AHP) after 1 week in vitro. This percentage increased to $67 \%$ after 5-6 weeks in culture $(n=15)$. Together, these findings suggest that cultured iPSCMNs mature over time and develop passive membrane and firing properties similar to their endogenous counterparts.
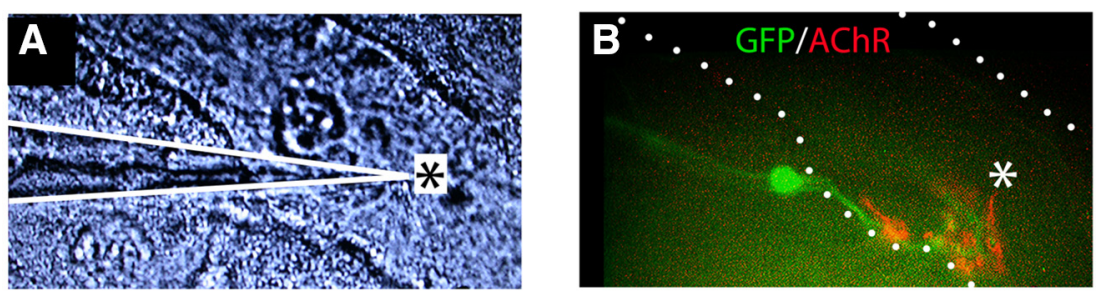

C

Control

$1 \mathrm{mV}$

\section{Glutamate $(100 \mu \mathrm{M})$}

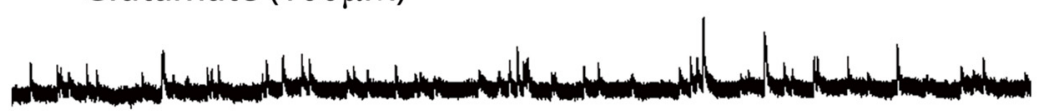

D

Control

$\operatorname{TTX}(25 \mu \mathrm{M})$
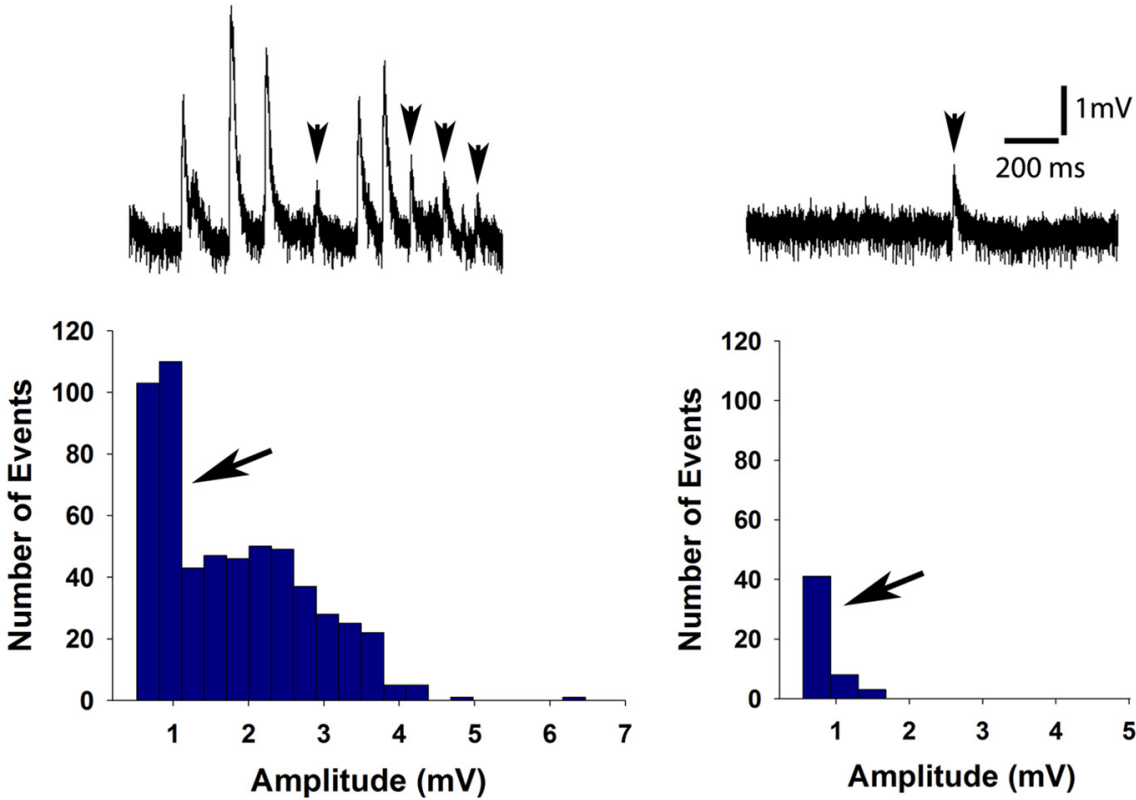

$\mathbf{E}$

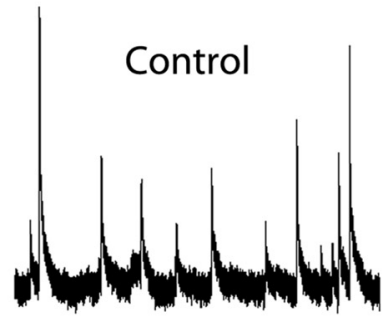

D-tubocurarine $(300 \mu \mathrm{M})$

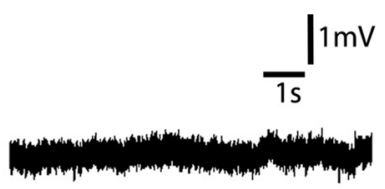

Figure 6. iPSCMNs form functional NMJs when cocultured with chick myofibers. A, DIC image of a chick myofiber impaled with a sharp electrode for intracellular recordings (placement of electrode indicated by white lines). $\boldsymbol{B}$, Innervated endplates were identified as a cluster of mAb35-labeled AChRs contacted by a single eGFP ${ }^{+}$. Asterisks in $\boldsymbol{A}$ and $\boldsymbol{B}$ denote region impaled by the recording electrode. $C$, Top trace shows EPPs recorded over a 5 s period in normal solution; bottom trace shows recording from the same cell after bath application of $100 \mu \mathrm{m}$ glutamate. Note the increase in number of EPPs. D, EPPs with an amplitude $>1.5 \mathrm{mV}$ were inhibited after bath application of $25 \mu \mathrm{M}$ TTX (right). Left, Recording from the same cell before TTX application. Histograms show the amplitudes of all EPPs recorded for $90 \mathrm{~s}$ in the absence (left) or presence (right) of TTX. E, Intracellular recordings in the absence (left) or presence (right) of bath applied D-tubocurarine ( $300 \mu \mathrm{M})$. Note the complete absence of EPPs in the right panel.

Implanted iPSCMNs innervate denervated muscle fibers and restore force after peripheral nerve injury

Embryonic rat ventral spinal cord cells (Thomas et al., 2000; Liu et al., 2013) and mouse ESCMNs (Yohn et al., 2008) restore skel- etal muscle function when transplanted into the distal stump of transected tibial nerves. To determine whether iPSCMNs have the same capacity, we cut the sciatic nerve and implanted $\sim 10,000$ iPSCMNs into the tibial nerve in mice $\sim 15 \mathrm{~mm}$ proxi- 
Table 3. Passive membrane properties of iPSCMNs

\begin{tabular}{lrrll}
\hline Weeks in culture & $n$ & $C_{\mathrm{m}}(\mathrm{pF})$ & $R_{\mathrm{m}}(\mathrm{M} \Omega)$ & $V_{\mathrm{m}}(\mathrm{mV})$ \\
\hline $1-2$ & 16 & $45.25 \pm 26.91^{* *}$ & $666.38 \pm 573.95^{* *}$ & $-45.19 \pm 9.47$ \\
$3-4$ & 9 & $121.33 \pm 45.15^{* *}$ & $189.33 \pm 104.37^{\wedge}$ & $-47.33 \pm 6.19$ \\
$5-6$ & 16 & $80.19 \pm 21.10^{* *}$ & $195.69 \pm 59.54^{\wedge}$ & $-50.44 \pm 7.84$ \\
\hline$C_{\mathrm{m}}$, Whole cell capacitance; $R_{\mathrm{m}}$, & membrane input resistance; $V_{\mathrm{m}}$, resting membrane potential. \\
Values are mean $\pm \mathrm{SD}$; ${ }^{*}$ statistically significant difference from all other means (one-way ANOVA, $p<0.05$ ), \\
^statistically significant difference from only the first mean (one-way ANOVA, $p<0.05)$.
\end{tabular}

mal to the medial gastrocnemius (MG) muscle. Reinnervation of muscles other than the MG was prevented by ligating all of the tibial nerve branches distal to the graft site (Fig. 9A; see also Yohn et al., 2008). Figure 9 shows an example of a typical graft containing multiple $\mathrm{eGFP}^{+}$iPSCMNs (Fig. 9Bi) extending neurites along the length of the distal tibial nerve stump (Fig. 9Bii) 5 weeks after transplantation. To assess synapse formation, we used rhodamine-conjugated $\alpha$-bungarotoxin to label AChRs at the MG motor endplates. Figure 9D shows an example of two eGFP ${ }^{+}$ axons with typical presynaptic morphologies (Fig. 9Di) innervating two $\mathrm{BTX}^{+}$motor endplates (Fig. 9Dii). These data collectively demonstrate that implanted iPSCMNs survive in a host peripheral nerve, extend axons, and form morphologically appropriate connections with denervated muscle fibers.

To determine whether the contacted endplates formed functional NMJs, we used an ex vivo nerve/muscle preparation to measure contractile force of the reinnervated MG muscles. Isometric twitch and tetanic contractions were elicited by applying single and repetitive electrical pulses $(50 \mathrm{~Hz}$ for $1 \mathrm{~s} ; 20 \mu$ s pulse duration) to the distal nerve stump via a suction electrode. Reinnervated muscle forces were compared with both an agematched, unoperated control MG muscle group in which the nerve was left intact and a surgical muscle control group in which the sciatic nerve was cut and ligated to prevent regeneration. The transected tibial nerve stumps of the surgical control group were injected with media alone. As expected, electrical stimulation of the tibial nerve stump in the control animals did not elicit muscle contraction (data not shown). In contrast, nerve/muscle preparations from mice implanted with iPSCMNs 6 weeks previously produced an average twitch force of $51.4 \pm 6.5 \mathrm{mN}(n=3)$ and tetanic force of $147 \pm 18 \mathrm{mN}(n=3)$, respectively (Fig. 9Fi,Fii). These values are $\sim 2 / 3$ that of unoperated age-matched control muscles, which produced twitch and tetanic forces of $80 \pm 7 \mathrm{mN}(n=3)$ and $203 \pm 15 \mathrm{mN}(n=3)$, respectively. Interestingly, the contractile forces of the muscles reinnervated by iPSCMNs, when calculated as a percentage of unoperated control values, were greater than those reported for rat and mouse MG muscles reinnervated by embryonic spinal cord cells (Thomas et al., 2000) or ESCMNs (Yohn et al., 2008). Although considerable force recovery was observed after implantation of iPSCMNs, twitch force profiles differed between treated and control groups (Fig. 9Ei). Rise times to peak force were significantly longer in the implanted group (76 $\pm 12 \mathrm{~ms})$ compared with control ( $47 \pm 5 \mathrm{~ms} ; n=3$ for each group, $p=0.022, t$ test), and relaxation times (measured as the time taken for the force to decline to half peak force value) were also significantly longer in the implanted group (implanted group $=52 \pm 12 \mathrm{~ms}$, control group $=28 \pm 8 \mathrm{~ms} ; n=3$ for each group, $p=0.046, t$ test). As expected from the force recordings, denervation-induced muscle atrophy was attenuated dramatically when the muscles were reinnervated by iPSCMNs (Fig. 9C). MG muscle diameter of implanted animals was significantly greater than those of surgical controls (control group $=2.94 \pm$ $0.08 \mathrm{~mm}$, implanted group $=2.19 \pm 0.05 \mathrm{~mm}$, surgical control group $=0.92 \pm 0.05 \mathrm{~mm} ; n=3$ for each group, $p<0.001$, one-way ANOVA, Holm-Sidak method; Fig. 9Gi). Further, the diameters of individual muscle fibers in the implanted group were significantly greater than those of the surgical control group (control $=34.5 \pm 9.4 \mu \mathrm{m}$, implanted group $=21.6 \pm 6.9 \mu \mathrm{m}$, surgical control group $=14.3 \pm 3.9 \mu \mathrm{m} ; n=90$ fibers, $n=3$ animals for each group, $p<0.001$, one-way ANOVA, HolmSidak method; Fig. 9Gii). Together, these results indicate that iPSCMNs form functional connections with denervated muscles fibers and that this innervation limits denervation atrophy.

\section{Discussion}

The present study provides a thorough assessment of iPSCMNs with respect to their capacity to develop into spinal motoneurons. Proteomic analysis revealed that iPSCMNs and ESCMNs have comparable protein expression profiles. The identified proteins in the ESCMNS and iPSCMNs were not only similarly grouped into known GO terms, but the proteins in each group were the same except for 143 binding proteins that were uniquely expressed in ESCMNs or iPSCMNs. These results indicate that the cellular makeup of ESCMNs and iPSCMNs are remarkably similar. In addition, when protein expression levels were compared between the two cell types, we found only 28 proteins to be upregulated and 87 proteins downregulated in iPSCMNs compared with ESCMNs. None of the upregulated or downregulated proteins is known to play a significant role in motoneuron differentiation. The remarkable similarities in protein identification and expression between ESCMNs and iPSCMNs suggest that these two cell types are very similar in nature. It will be interesting nonetheless to pursue whether proteins identified as being differentially regulated can affect motoneuron phenotypes that are more subtle than those used in this study. For example, BetaIVSigmal spectrin (Sptbn4 in Table 2) is concentrated at the nodes of Ranvier in the peripheral nervous system (Berghs et al., 2000) and regulates, at least in part, its size (Lacas-Gervais et al., 2004). Whether the nodes of Ranvier would differ between iPSCMNs and ESCMNs remains to be determined.

Interestingly, even though we focused on 15 transcription factors involved in neuron and/or motoneuron differentiation, only Myt1l was identified in our dataset. Myt1l was not differentially expressed in ESCMNs and iPSCMNs. The reasons that we did not detect more transcription factors involved in motoneuron differentiation in unclear, but likely reflects the proteomic approach used in this study. Some peptides are better at being ionized and thus are more amenable to identification in a mass spectrometer. Future studies could use a more targeted approach using multiple reaction monitoring analysis to identify all known transcription factors involved. Despite this limitation, the present study indicates that the protein compositions of motoneurons derived from ESCs and iPSCs are remarkably similar.

\section{Axonal trajectories of iPSCMNs are appropriate for their LIM homeodomain expression pattern}

Similarities in LIM homeodomain protein expression between ESCMNs and iPSCMNs suggest that they undergo similar developmental programs when cultured in the presence of SAG and RA. The vast majority of ESCMNs (Soundararajan et al., 2006) and iPSCMNs were immunopositive for the Lhx3 (Fig. 2), a LIM homeodomain protein expressed by motoneurons in the medial aspect of the medial motor column (Sharma et al., 1998). Like ESCMNs (Soundararajan et al., 2006; Soundararajan et al., 2007; Soundararajan et al., 2010), their axonal trajectories reflected the nature of their LIM homeodomain protein expression pattern 
A
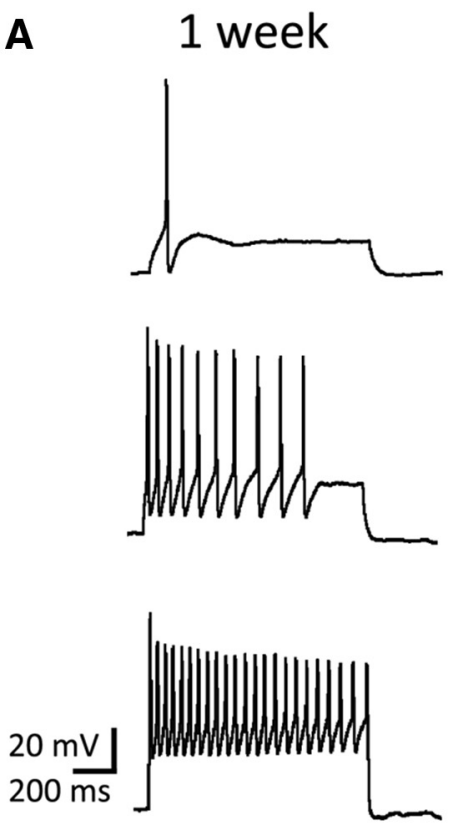

B

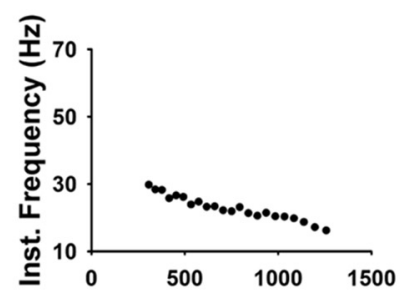

C

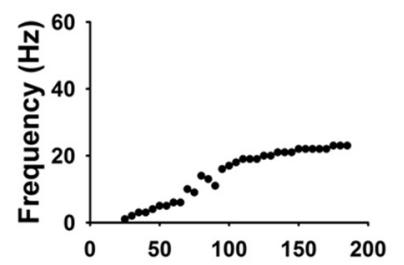

2 weeks
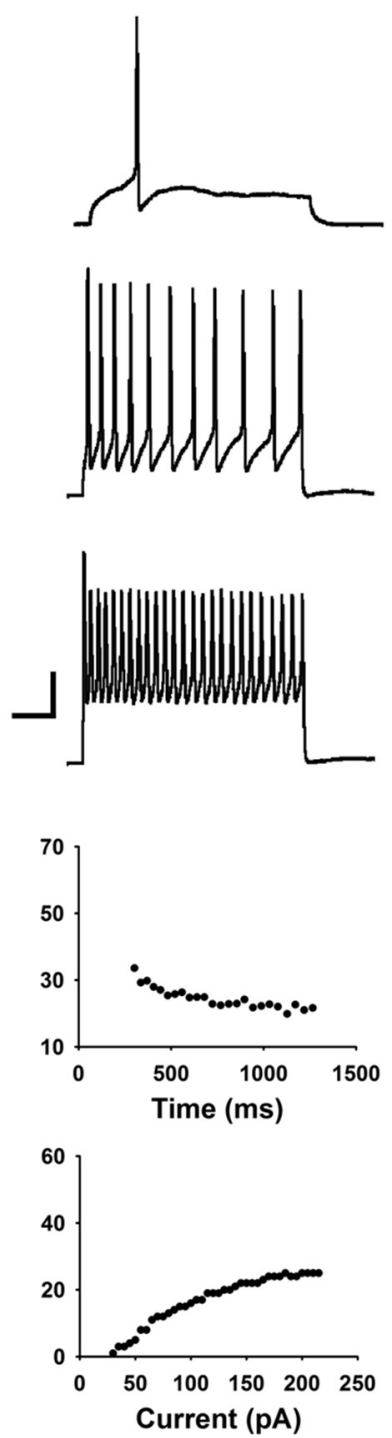

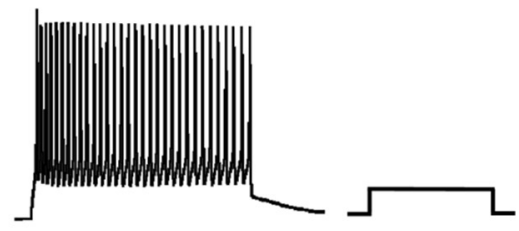

5 weeks
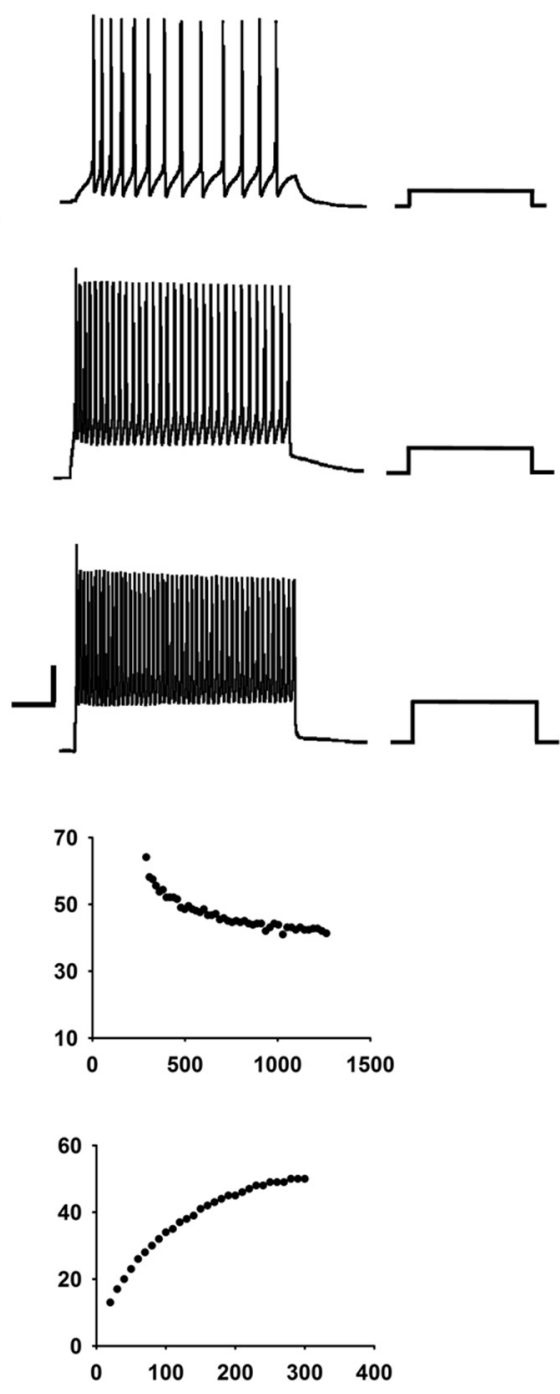

Figure 7. iPSCMNs develop appropriate motoneuron firing properties. $A$, Current-clamp recordings of membrane potentials in response to $500 \mathrm{~ms}$ current injections measured from iPSCMNs after 1,2 , and 5 weeks in vitro. iPSCMNs were capable of firing repetitive action potentials at all ages, however, the amount current required decreased with age. Values of injected current (from top to bottom trace, respectively) for 1 week were 25,70 , and $110 \mathrm{pA}$; for 2 weeks, they were 30,65 , and $185 \mathrm{pA}$; and for 5 weeks, they were 20,90, and $220 \mathrm{pA}$. B, Plots of instantaneous firing frequency versus time during a single current pulse shows spike frequency adaptation. C, Plot showing that maximum firing frequency increases with days in culture (i.e., 1,2, and 5 weeks).

when transplanted into the neural tube of developing chick embryos at the time of motoneurogenesis. The majority of iPSCMNs projected axons out of the ventral root and then dorsally around the DRG to the epaxial muscles along nerve pathways taken by developing chick Lhx $3^{+}$motoneurons (Fig. 3). Far fewer axons targeted limb musculature. These results suggest that iPSCMNs express guidance factors necessary for this targeting, such as EphA4 (expressed by both $\mathrm{Lhxl}^{+}$motoneurons that innervate the dorsal limb muscle mass as well as Lhx $3^{+}$motoneurons that innervate epaxial muscles) and FGFR1 (expressed by Lhx $3^{+}$motoneurons). Both molecules are known to be required for proper guidance of developing Lhx $3^{+}$motoneurons (Helmbacher et al., 2000; Shirasaki et al., 2006; Soundararajan et al., 2010).

\section{iPSCMNs form functional NMJs in vitro}

Previous studies have shown that iPSCMNs contact myotubes formed from muscle cell lines (i.e., C2C12 cells) and extend neurites in close vicinity to AChR clusters ( $\mathrm{Hu}$ and Zhang, 2009;
Mitne-Neto et al., 2011). The present study extends these findings to show that iPSCMNs form stable NMJs with anatomical and physiological features typical of mature endplates when cocultured with chick myotubes for several weeks. Anatomically, iPSCMNs initially formed endplates that were plaque shaped (Fig. $4 E$ ) but later became characteristically pretzel shaped (Fig. $4 K)$. This transition in endplate appearance normally occurs during the first postnatal weeks in mice and likely involves bidrectional signaling between motoneurons and muscle fibers (Balice-Gordon et al., 1993; Bolliger et al., 2010). Our SV2 immunolabeling (Fig. 4L) and FM dye studies (Fig. 5) indicated that iPSMNCs correctly localized synaptic vesicles at endplates, where they cycled appropriately in response to neural stimulation (Betz and Bewick, 1992; Ribchester et al., 1994). Furthermore, we showed that EPPs and TTX-insensitive mEPPs were present at NMJs formed by iPSCMNs in vitro (Fig. 6), indicating that the junctions were functional and capable of inducing depolarization in postsynaptic myofibers. As expected, the largest EPPs were 


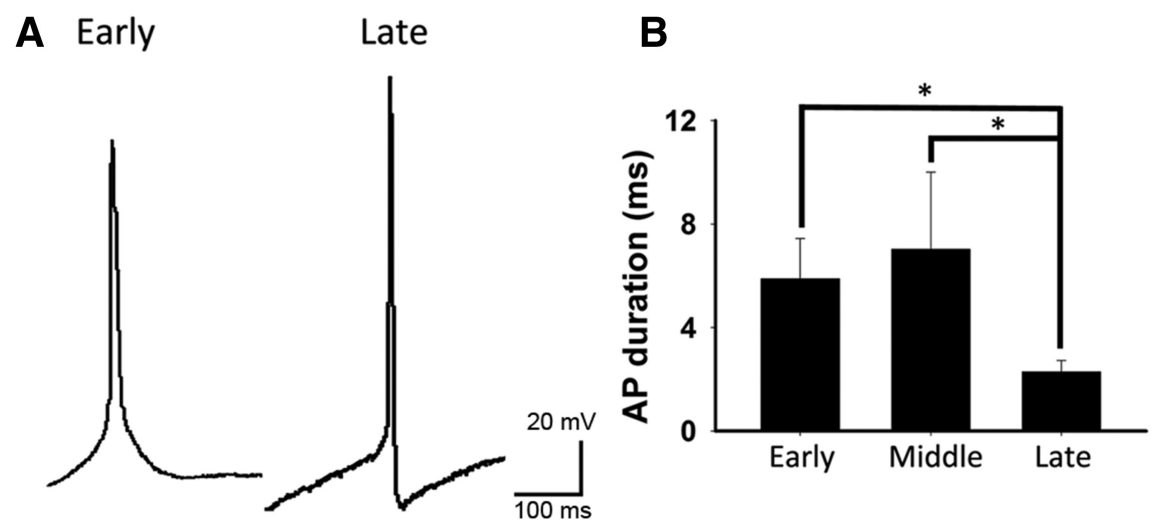

Figure 8. iPSCMNs action potential profiles mature with age. $\boldsymbol{A}$, Representative spikes at early and late time points after injection of depolarizing current. Note the presence of the afterhyperpolarization in the action potential (AP) generated at the late time point. $\boldsymbol{B}$, AP duration (measured at half-maximum peak amplitude) significantly decreases as motoneurons mature (KruskalWallis one-way ANOVA on ranks, $p<0.05$ for early $(n=11)$ versus late $(n=10)$ and middle $(n=8)$ versus late. Early, $9-14 \mathrm{~d}$ in culture; middle, $21-29$ d in culture; late, $37-43 \mathrm{~d}$ in culture.

blocked upon bath application of D-tubocararine, indicating that they were induced through cholinergic stimulation (Fischbach and Cohen, 1973). Together, our results strongly indicate that iPSCMNs develop multiple characteristics of endogenous motoneurons, including the acquisition of appropriate synaptic machinery for neurotransmission and nerve-derived signals (McMahan, 1990; Bezakova and Ruegg, 2003; presumably agrin) that form, stabilize, and mature the NMJ throughout development.

\section{Passive membrane and firing properties of iPSCMNs}

The present work extends upon previous electrophysiological studies on iPSCMNs (Karumbayaram et al., 2009; Hu et al., 2010; Bilican et al., 2012; Egawa et al., 2012; Yao et al., 2013) by characterizing passive and active membrane properties for several weeks after differentiation. Trends in maturation of passive membrane properties of iPSCMNs resembled those seen in developing motoneurons in vivo (Fulton and Walton, 1986; Gao and Ziskind-Conhaim, 1998; Nakanishi and Whelan, 2010). Membrane resistance progressively decreased over the first few weeks in culture, concomitant with an increase in membrane capacitance. Both changes occur during normal motoneuron devlopment (Ulfhake and Cullheim, 1988) and are indicative of an overall increase in cell size over time. We also showed that iPSCMNs develop firing properties such as fast-firing action potentials and spike frequency adaptation in response to injections of depolarizing current (Fig. 7). Both firing properties are signatures of endogenous motoneurons (Granit et al., 1963; Kernell and Monster, 1982) and ESCMNs (Miles et al., 2004). In addition, an increasing proportion of motoneurons developed AHPs (38-67\%) typical of endogenous motoneurons (Fulton and Walton, 1986) 1 week after plating. Together, these results suggest that iPSCMNs acquire voltage-gated channel properties characteristics of normal spinal motoneurons. The few differences observed between iPSCMNs and endogenous motoneurons (i.e., AHPs being absent in 33\% of iPSCMNs after 5 weeks in vitro) may be due to intrinsic differences between the two cell types or it could simply reflect differences in growth environment. Further studies will be required to determine whether addition of spinal interneurons, sensory neurons, glial cells, and/or myofibers to the cultures would further the development of iPSCMNs into more mature motoneurons.
Implanted iPSCMNs project axons to target muscle and promote force recovery after injury

Denervated murine muscles recover $\sim 10 \%$ of their original contractile force values when reinnervated by embryonic ventral spinal cord cells transplanted into the peripheral nerve near the muscle/ nerve entry point (Thomas et al., 2000). Recovery of force is improved if trophic factors are added to the graft at the time of transplant (Grumbles et al., 2009) or if the cells were stimulated for $1 \mathrm{~h}$ immediately after transplantation (Grumbles et al., 2013). ESCMNs also reinnervate denervated muscle fibers, reduce muscle atrophy, and restore contractile force to $40 \%$ that of control muscles when transplanted near the MG nerve/muscle entry point in mice (Yohn et al., 2008). In the present study, iPSCMNs formed anatomically normal NMJs (Fig. 9D; see also Su et al., 2013) with previously denervated muscle fibers when transplanted near the mouse MG nerve/muscle entry point. Interestingly, the contractile force of the MG muscles reinnervated by iPSCMNs was $\sim 70 \%$ that of control values (Fig. $9 F$ ). Therefore, iPSCMNs are at least as efficient as embryonic spinal neurons (Thomas et al., 2000) and ESCMNs (Yohn et al., 2008) in restoring force to denervated muscles when transplanted into the distal nerve.

As observed for grafted ESCMNs (Yohn et al., 2008), transplanted iPSCMNs dramatically reduced muscle atrophy associated with denervation (Fig. 9G). These results indicate that iPSCMNs in the graft were actively inducing muscle fiber contractions by firing action potentials. This assumption is based on previous studies in which marked muscle atrophy was shown to occur in animal models of chronic disuse even when myofibers were stretched passively (Roy et al., 1998). That is, atrophy is only prevented if the innervated myofibers are actively contracting. Furthermore, the slower rise times of the twitch contractions in muscles reinnervated by iPSCMNs compared with the contralateral control muscles indicates that the transplanted neurons were active for a significant period of time during the day (Kernell et al., 1987). This supposition is based on the wealth of studies showing that slowing of contractile speed occurs with increased neuromuscular activity (for review, see Gordon and Pattullo, 1993). It is presently not known why iPSCMNs fire action potentials in the transplants, but it is likely due to mechanical stimulation by surrounding tissue and/or by glutamatergic excitation from additional neurons in the graft that differentiated with the motoneurons before transplantation (Yohn et al., 2008; Chipman et al., 2014).

\section{iPSCMNs: future considerations}

The results in this study further endorse the use of iPSCMNs to study the pathology of motoneuron diseases such as ALS (Bilican et al., 2012; Egawa et al., 2012; Burkhardt et al., 2013; Serio et al., 2013; Yao et al., 2013) and spinal muscular atrophy (Corti et al., 2012). Recent studies using iPSCMNs from ALS patients to screen drugs promoting motoneuron survival have also yielded novel findings that would likely not have been achieved without this technology (Yang et al., 2013). However, most studies to date have examined iPSCMN behavior in isolation over short periods 

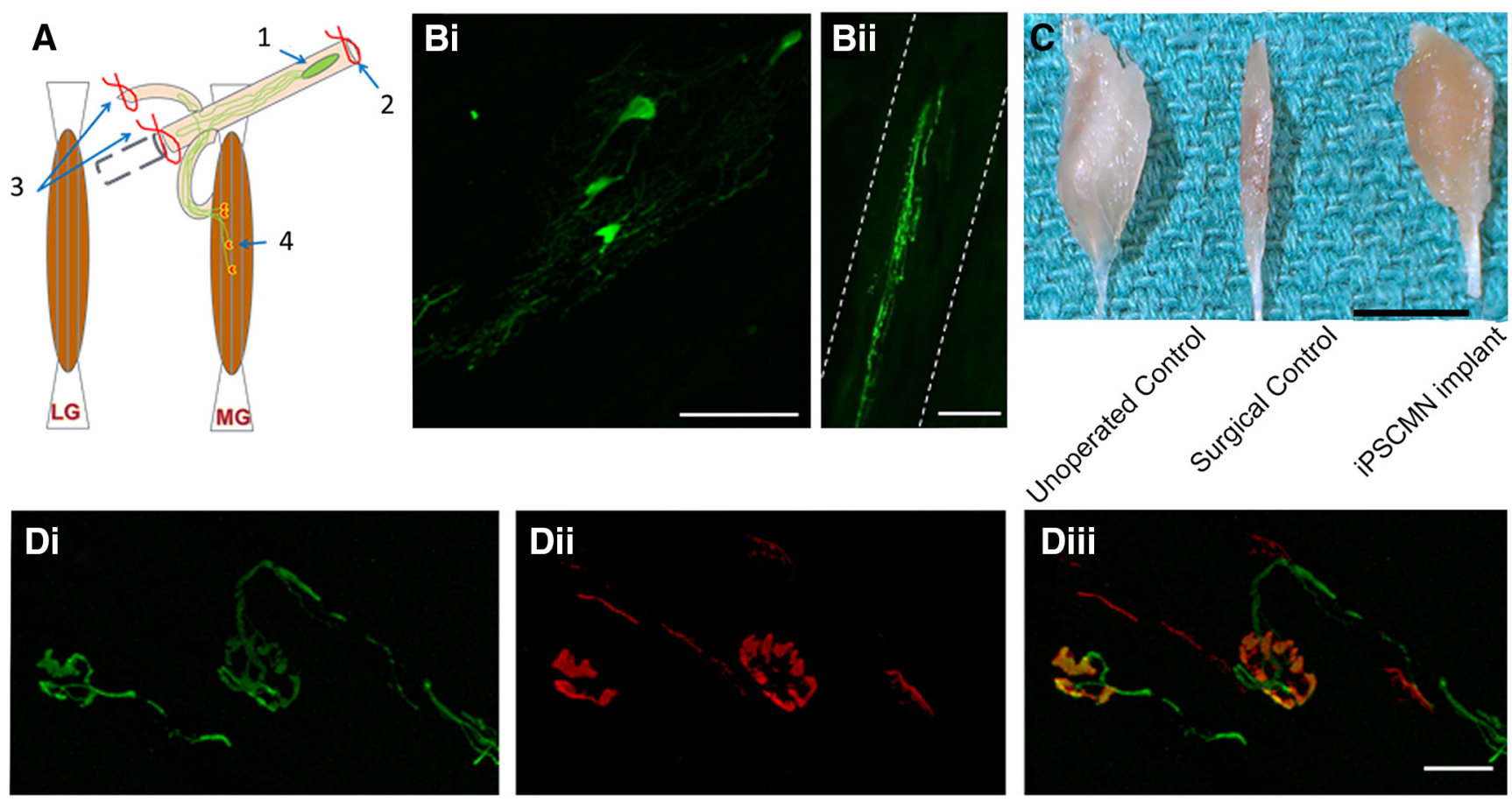

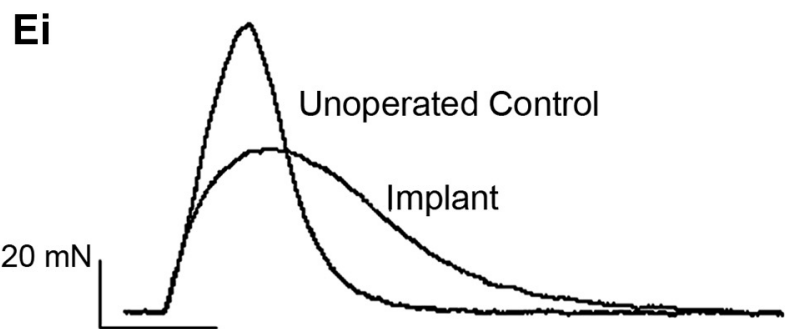

$50 \mathrm{~ms}$
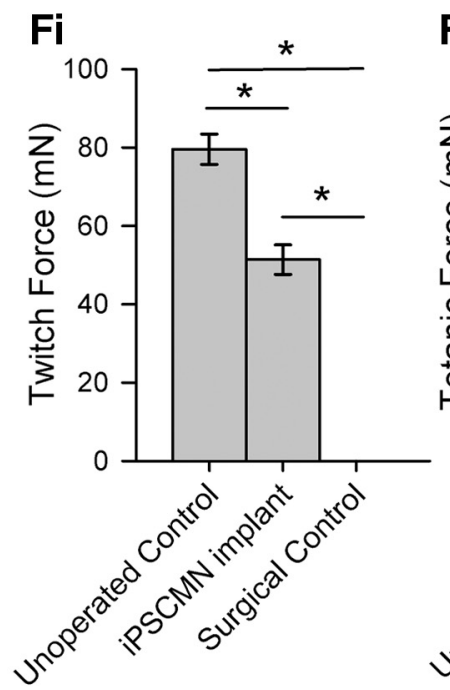

Fii

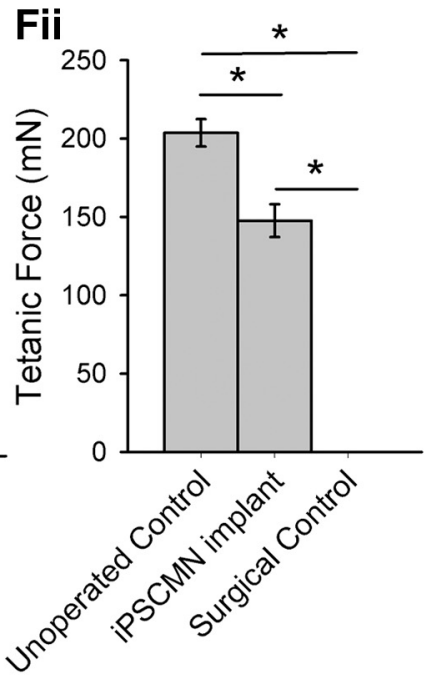

Eii

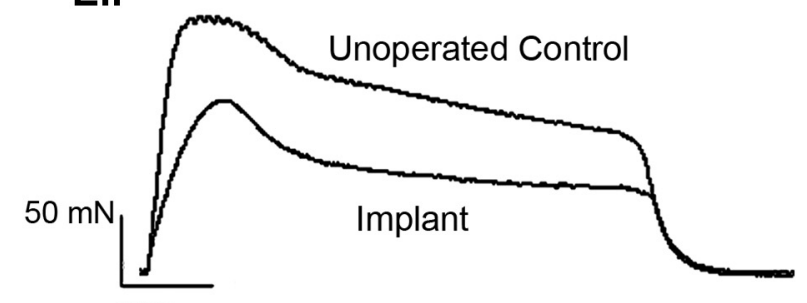

$200 \mathrm{~ms}$

Gi

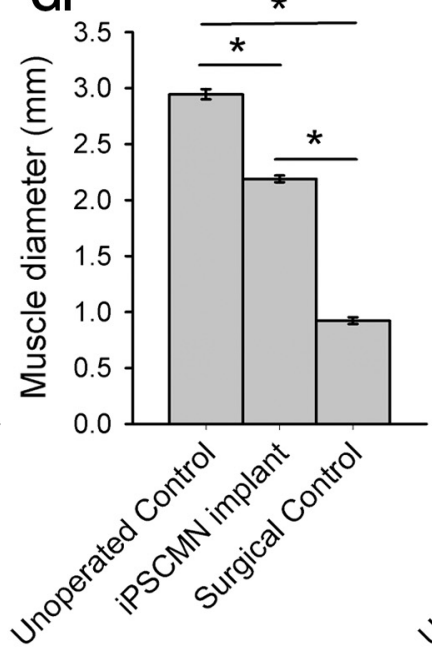

Gii

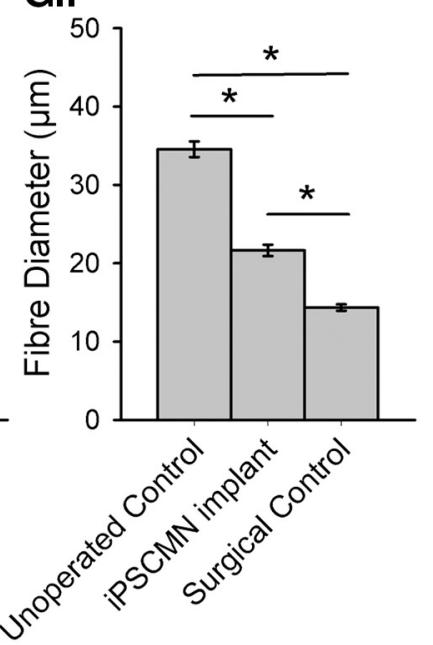

Figure 9. Implanted iPSCMNs form anatomical connections with host muscle fibers, promote recovery of muscle force, and maintain muscle size after nerve injury. $\boldsymbol{A}$, Schematic depiction of site of implantation of iPSCMNs with associated axon growth and connectivity to host muscle fibers: (1) iPSCMNs graft site in tibial nerve, (2) ligation distal to transection site, (3) transection and ligation of all nerves except the MG, and (4) presumptive reinnervation of denervated MG endplates. B, eGFP ${ }^{+}{ }^{i}$ PSCMN cell bodies are clearly evident within the graft 5 weeks (Bi) after transplantation, and $\mathrm{GFP}^{+}$axons were also present in the MG nerve at the same timepoint (Bii). C, Photograph showing MG muscles reinnervated by iPSCMNs (iPSCMN implant) were comparable in size to unoperated control muscles (unoperated control) and less atrophied than completely denervated muscles (surgical control) 6 weeks after surgery. D, eGFP ${ }^{+}$axons (Di) contact $\alpha$-btx labeled AChRs (Dii) in denervated MG muscles 5 weeks after transplantation. Diii is a merged image of Di and Dii. E, MG muscle force profiles elicited by a single electrical pulse (EI) or by a train of pulses ( $50 \mathrm{~Hz}$ for $1 \mathrm{~s}$; Eii) to control tibial nerves (unoperated control) and nerves implanted with iPSCMNs 5 weeks previously. $\boldsymbol{F}$, Twitch ( $\boldsymbol{F}$ ) and tentanic of forces (Fii; mean \pm SD) of unoperated control, MG muscles reinnervated by implanted iPSCMNs, and completely denervated MG muscles (surgical control) 6 weeks after transplantation. ( $n=3$ for each group). G, Mean ( \pm SD) diameter of the MG muscles (Gi) and muscle fibers (Gii) described in F. Scale bars: Bi, $50 \mu \mathrm{m} ;$ Bii, $100 \mu \mathrm{m} ; \mathbf{C}, 5 \mathrm{~mm}$; Diii, $50 \mu \mathrm{m}$. 
of time or iPSCMNs cocultured with cells within the CNS rather than cells found in the periphery. Because motor axons withdraw from endplates before cell death (Fischer et al., 2004), future studies should also include long-term iPSCMN/myofiber cocultures. This assertion is underscored by the fact that the onset of symptoms associated with ALS occurs later in life and that neuroprotection alone is insufficient to attenuate disease progression (Gould et al., 2006). Finally, the finding that iPSCMNs remain functional several weeks after transplantation lends support to their use in cell-replacement therapies designed to restore function to permanently denervated muscles after injury. However, additional preclinical studies must be performed to determine how iPSCMNs interact with host cells over an extended period of time and whether nondifferentiated cells in the graft pose any long-term threats to the recipient.

\section{References}

Alaynick WA, Jessell TM, Pfaff SL (2011) SnapShot: spinal cord development. Cell 146:178-178.e1. CrossRef Medline

Arber S, Han B, Mendelsohn M, Smith M, Jessell TM, Sockanathan S (1999) Requirement for the homeobox gene $\mathrm{Hb} 9$ in the consolidation of motor neuron identity. Neuron 23:659-674. CrossRef Medline

Balice-Gordon RJ, Chua CK, Nelson CC, Lichtman JW (1993) Gradual loss of synaptic cartels precedes axon withdrawal at developing neuromuscular junctions. Neuron 11:801-815. CrossRef Medline

Berghs S, Aggujaro D, Dirkx R Jr, Maksimova E, Stabach P, Hermel JM, Zhang JP, Philbrick W, Slepnev V, Ort T, Solimena M (2000) betaIV spectrin, a new spectrin localized at axon initial segments and nodes of ranvier in the central and peripheral nervous system. J Cell Biol 151:9851002. CrossRef Medline

Betz WJ, Bewick GS (1992) Optical analysis of synaptic vesicle recycling at the frog neuromuscular junction. Science 255:200-203. CrossRef Medline

Bezakova G, Ruegg MA (2003) New insights into the roles of agrin. Nat Rev Mol Cell Biol 4:295-308. CrossRef Medline

Bilican B, Serio A, Barmada SJ, Nishimura AL, Sullivan GJ, Carrasco M, Phatnani HP, Puddifoot CA, Story D, Fletcher J, Park IH, Friedman BA, Daley GQ, Wyllie DJ, Hardingham GE, Wilmut I, Finkbeiner S, Maniatis T, Shaw CE, Chandran S (2012) Mutant induced pluripotent stem cell lines recapitulate aspects of TDP-43 proteinopathies and reveal cellspecific vulnerability. Proc Natl Acad Sci U S A 109:5803-5808. CrossRef Medline

Bolliger MF, Zurlinden A, Lüscher D, Bütikofer L, Shakhova O, Francolini M, Kozlov SV, Cinelli P, Stephan A, Kistler AD, Rülicke T, Pelczar P, Ledermann B, Fumagalli G, Gloor SM, Kunz B, Sonderegger P (2010) Specific proteolytic cleavage of agrin regulates maturation of the neuromuscular junction. J Cell Sci 123:3944-3955. CrossRef Medline

Burkhardt MF, Martinez FJ, Wright S, Ramos C, Volfson D, Mason M, Garnes J, Dang V, Lievers J, Shoukat-Mumtaz U, Martinez R, Gai H, Blake R, Vaisberg E, Grskovic M, Johnson C, Irion S, Bright J, Cooper B, Nguyen L, et al. (2013) A cellular model for sporadic ALS using patient-derived induced pluripotent stem cells. Mol Cell Neurosci 56:355-364. CrossRef Medline

Chen XL, Zhong ZG, Yokoyama S, Bark C, Meister B, Berggren PO, Roder J, Higashida H, Jeromin A (2001) Overexpression of rat neuronal calcium sensor-1 in rodent NG108-15 cells enhances synapse formation and transmission. J Physiol 532:649-659. CrossRef Medline

Chipman PH, Toma JS, Rafuse VF (2012) Generation of motor neurons from pluripotent stem cells. Prog Brain Res 201:313-331. CrossRef Medline

Chipman PH, Zhang Y, Rafuse VF (2014) A stem-cell based bioassay to critically assess the pathology of dysfunctional neuromuscular junctions. PLoS One 9:e91643. CrossRef Medline

Corti S, Nizzardo M, Simone C, Falcone M, Nardini M, Ronchi D, Donadoni C, Salani S, Riboldi G, Magri F, Menozzi G, Bonaglia C, Rizzo F, Bresolin N, Comi GP (2012) Genetic correction of human induced pluripotent stem cells from patients with spinal muscular atrophy. Sci Transl Med 4:165ra162. CrossRef Medline

Dahm LM, Landmesser LT (1991) The regulation of synaptogenesis during normal development and following activity blockade. J Neurosci 11:238255. Medline

Dimos JT, Rodolfa KT, Niakan KK, Weisenthal LM, Mitsumoto H, Chung W, Croft GF, Saphier G, Leibel R, Goland R, Wichterle H, Henderson CE, Eggan K (2008) Induced pluripotent stem cells generated from patients with ALS can be differentiated into motor neurons. Science 321:1218 1221. CrossRef Medline

Egawa N, Kitaoka S, Tsukita K, Naitoh M, Takahashi K, Yamamoto T, Adachi F, Kondo T, Okita K, Asaka I, Aoi T, Watanabe A, Yamada Y, Morizane A, Takahashi J, Ayaki T, Ito H, Yoshikawa K, Yamawaki S, Suzuki S, et al. (2012) Drug screening for ALS using patient-specific induced pluripotent stem cells. Sci Transl Med 4:145ra104. Medline

Fischbach GD, Cohen SA (1973) The distribution of acetylcholine sensitivity over uninnervated and innervated muscle fibers grown in cell culture. Dev Biol 31:147-162. CrossRef Medline

Fischer LR, Culver DG, Tennant P, Davis AA, Wang M, Castellano-Sanchez A, Khan J, Polak MA, Glass JD (2004) Amyotrophic lateral sclerosis is a distal axonopathy: evidence in mice and man. Exp Neurol 185:232-240. CrossRef Medline

Fulton BP, Walton K (1986) Electrophysiological properties of neonatal rat motoneurones studied in vitro. J Physiol 370:651-678. Medline

Gaffield MA, Betz WJ (2006) Imaging synaptic vesicle exocytosis and endocytosis with FM dyes. Nat Protoc 1:2916-2921. CrossRef Medline

Gao BX, Ziskind-Conhaim L (1998) Development of ionic currents underlying changes in action potential waveforms in rat spinal motoneurons. J Neurophysiol 80:3047-3061. Medline

Gordon T, Pattullo MC (1993) Plasticity of muscle fiber and motor unit types. Exerc Sport Sci Rev 21:331-362. Medline

Gould TW, Buss RR, Vinsant S, Prevette D, Sun W, Knudson CM, Milligan CE, Oppenheim RW (2006) Complete dissociation of motor neuron death from motor dysfunction by Bax deletion in a mouse model of ALS. J Neurosci 26:8774-8786. CrossRef Medline

Granit R, Kernell D, Shortess GK (1963) Quatitative aspects of repetitive firing of mammalian motoneurones, caused by injected currents. J Physiol 168:911-931. Medline

Grumbles RM, Sesodia S, Wood PM, Thomas CK (2009) Neurotrophic factors improve motoneuron survival and function of muscle reinnervated by embryonic neurons. J Neuropathol Exp Neurol 68:736-746. CrossRef Medline

Grumbles RM, Liu Y, Thomas CM, Wood PM, Thomas CK (2013) Acute stimulation of transplanted neurons improves motoneuron survival, axon growth, and muscle reinnervation. J Neurotrauma 30:1062-1069. CrossRef Medline

Helmbacher F, Schneider-Maunoury S, Topilko P, Tiret L, Charnay P (2000) Targeting of the EphA4 tyrosine kinase receptor affects dorsal/ventral pathfinding of limb motor axons. Development 127:3313-3324. Medline

Hennig R, Lømo T (1985) Firing patterns of motor units in normal rats. Nature 314:164-166. CrossRef Medline

Hu BY, Zhang SC (2009) Differentiation of spinal motor neurons from pluripotent human stem cells. Nat Protoc 4:1295-1304. CrossRef Medline

Hu BY, Weick JP, Yu J, Ma LX, Zhang XQ, Thomson JA, Zhang SC (2010) Neural differentiation of human induced pluripotent stem cells follows developmental principles but with variable potency. Proc Natl Acad Sci U S A 107:4335-4340. CrossRef Medline

Jiang ZG, Shen E, Dun NJ (1990) Excitatory and inhibitory transmission from dorsal root afferents to neonate rat motoneurons in vitro. Brain Res 535:110-118. CrossRef Medline

Kania A, Johnson RL, Jessell TM (2000) Coordinate roles for LIM homeobox genes in directing the dorsoventral trajectory of motor axons in the vertebrate limb. Cell 102:161-173. CrossRef Medline

Karumbayaram S, Novitch BG, Patterson M, Umbach JA, Richter L, Lindgren A, Conway AE, Clark AT, Goldman SA, Plath K, Wiedau-Pazos M, Kornblum HI, Lowry WE (2009) Directed differentiation of human-induced pluripotent stem cells generates active motor neurons. Stem Cells 27:806811. CrossRef Medline

Kernell D, Monster AW (1982) Time course and properties of late adaptation in spinal motoneurones of the cat. Exp Brain Res 46:191-196. CrossRef Medline

Kernell D, Eerbeek O, Verhey BA, Donselaar Y (1987) Effects of physiological amounts of high- and low-rate chronic stimulation on fast-twitch muscle of the cat hindlimb. I. Speed- and force-related properties. J Neurophysiol 58:598-613. Medline 
Lacas-Gervais S, Guo J, Strenzke N, Scarfone E, Kolpe M, Jahkel M, De Camilli P, Moser T, Rasband MN, Solimena M (2004) BetaIVSigmal spectrin stabilizes the nodes of Ranvier and axon initial segments. J Cell Biol 166:983-990. CrossRef Medline

Liu Y, Grumbles RM, Thomas CK (2013) Electrical stimulation of embryonic neurons for 1 hour improves axon regeneration and the number of reinnervated muscles that function. J Neuropathol Exp Neurol 72:697707. CrossRef Medline

López-González R, Velasco I (2012) Therapeutic potential of motor neurons differentiated from embryonic stem cells and induced pluripotent stem cells. Arch Med Res 43:1-10. CrossRef Medline

Lupa MT, Hall ZW (1989) Progressive restriction of synaptic vesicle protein to the nerve terminal during development of the neuromuscular junction. J Neurosci 9:3937-3945. Medline

McMahan UJ (1990) The agrin hypothesis. Cold Spring Harb Symp Quant Biol 55:407-418. CrossRef Medline

Miles GB, Yohn DC, Wichterle H, Jessell TM, Rafuse VF, Brownstone RM (2004) Functional properties of motoneurons derived from mouse embryonic stem cells. J Neurosci 24:7848-7858. CrossRef Medline

Mitne-Neto M, Machado-Costa M, Marchetto MC, Bengtson MH, Joazeiro CA, Tsuda H, Bellen HJ, Silva HC, Oliveira AS, Lazar M, Muotri AR, Zatz M (2011) Downregulation of VAPB expression in motor neurons derived from induced pluripotent stem cells of ALS8 patients. Hum Mol Genet 20:3642-3652. CrossRef Medline

Nakanishi ST, Whelan PJ (2010) Diversification of intrinsic motoneuron electrical properties during normal development and botulinum toxininduced muscle paralysis in early postnatal mice. J Neurophysiol 103: 2833-2845. CrossRef Medline

Phillips WD, Lai K, Bennett MR (1985) Spatial distribution and size of acetylcholine receptor clusters determined by motor nerves in developing chick muscles. J Neurocytol 14:309-325. CrossRef Medline

Pinter MJ, Curtis RL, Hosko MJ (1983) Voltage threshold and excitability among variously sized cat hindlimb motoneurons. J Neurophysiol 50: 644-657. Medline

Ribchester RR, Mao F, Betz WJ (1994) Optical measurements of activitydependent membrane recycling in motor nerve terminals of mammalian skeletal muscle. Proc Biol Sci 255:61-66. CrossRef Medline

Robbins N, Yonezawa T (1971) Physiological studies during formation and development of rat neuromuscular junctions in tissue culture. J Gen Physiol 58:467-481. CrossRef Medline

Roy RR, Pierotti DJ, Baldwin KM, Zhong H, Hodgson JA, Edgerton VR (1998) Cyclical passive stretch influences the mechanical properties of the inactive cat soleus. Exp Physiol 83:377-385. Medline

Serio A, Bilican B, Barmada SJ, Ando DM, Zhao C, Siller R, Burr K, Haghi G, Story D, Nishimura AL, Carrasco MA, Phatnani HP, Shum C, Wilmut I, Maniatis T, Shaw CE, Finkbeiner S, Chandran S (2013) Astrocyte pathology and the absence of non-cell autonomy in an induced pluripotent stem cell model of TDP-43 proteinopathy. Proc Natl Acad Sci U S A 110:4697-4702. CrossRef Medline

Sharma K, Sheng HZ, Lettieri K, Li H, Karavanov A, Potter S, Westphal H, Pfaff SL (1998) LIM homeodomain factors Lhx3 and Lhx4 assign subtype identities for motor neurons. Cell 95:817-828. CrossRef Medline

Sharma K, Leonard AE, Lettieri K, Pfaff SL (2000) Genetic and epigenetic mechanisms contribute to motor neuron pathfinding. Nature 406:515519. CrossRef Medline
Shirasaki R, Lewcock JW, Lettieri K, Pfaff SL (2006) FGF as a target-derived chemoattractant for developing motor axons genetically programmed by the LIM code. Neuron 50:841-853. CrossRef Medline

Slater CR (1982) Postnatal maturation of nerve-muscle junctions in hindlimb muscles of the mouse. Dev Biol 94:11-22. CrossRef Medline

Son EY, Ichida JK, Wainger BJ, Toma JS, Rafuse VF, Woolf CJ, Eggan K (2011) Conversion of mouse and human fibroblasts into functional spinal motor neurons. Cell Stem Cell 9:205-218. CrossRef Medline

Soundararajan P, Miles GB, Rubin LL, Brownstone RM, Rafuse VF (2006) Motoneurons derived from embryonic stem cells express transcription factors and develop phenotypes characteristic of medial motor column neurons. J Neurosci 26:3256-3268. CrossRef Medline

Soundararajan P, Lindsey BW, Leopold C, Rafuse VF (2007) Easy and rapid differentiation of embryonic stem cells into functional motoneurons using sonic hedgehog-producing cells. Stem Cells 25:1697-1706. CrossRef Medline

Soundararajan P, Fawcett JP, Rafuse VF (2010) Guidance of postural motoneurons requires MAPK/ERK signaling downstream of fibroblast growth factor receptor 1. J Neurosci 30:6595-6606. CrossRef Medline

Su H, Wang L, Cai J, Yuan Q, Yang X, Yao X, Wong WM, Huang W, Li Z, Wan JB, Wang Y, Pei D, So KF, Qin D, Wu W (2013) Transplanted motoneurons derived from human induced pluripotent stem cells form functional connections with target muscle. Stem Cell Res 11:529-539. CrossRef Medline

Thomas CK, Erb DE, Grumbles RM, Bunge RP (2000) Embryonic cord transplants in peripheral nerve restore skeletal muscle function. J Neurophysiol 84:591-595. Medline

Tosney KW, Landmesser LT (1985) Development of the major pathways for neurite outgrowth in the chick hindlimb. Dev Biol 109:193-214. CrossRef Medline

Tsuchida T, Ensini M, Morton SB, Baldassare M, Edlund T, Jessell TM, Pfaff SL (1994) Topographic organization of embryonic motor neurons defined by expression of LIMhomeobox genes. Cell 79:957-970. CrossRef Medline

Ulfhake B, Cullheim S (1988) Postnatal development of cat hind limb motoneurons. III: Changes in size of motoneurons supplying the triceps surae muscle. J Comp Neurol 278:103-120. CrossRef Medline

Wichterle H, Lieberam I, Porter JA, Jessell TM (2002) Directed differentiation of embryonic stem cells into motor neurons. Cell 110:385-397. CrossRef Medline

Xie H, Ziskind-Conhaim L (1995) Blocking Ca(2+)-dependent synaptic release delays motoneuron differentiation in the rat spinal cord. J Neurosci 15:5900-5911. Medline

Yang YM, Gupta SK, Kim KJ, Powers BE, Cerqueira A, Wainger BJ, Ngo HD, Rosowski KA, Schein PA, Ackeifi CA, Arvanites AC, Davidow LS, Woolf CJ, Rubin LL (2013) A small molecule screen in stem-cell-derived motor neurons identifies a kinase inhibitor as a candidate therapeutic for ALS. Cell Stem Cell 12:713-726. CrossRef Medline

Yao XL, Ye CH, Liu Q, Wan JB, Zhen J, Xiang AP, Li WQ, Wang Y, Su H, Lu XL (2013) Motoneuron differentiation of induced pluripotent stem cells from SOD1G93A mice. PLoS One 8:e64720. CrossRef Medline

Yohn DC, Miles GB, Rafuse VF, Brownstone RM (2008) Transplanted mouse embryonic stem-cell-derived motoneurons form functional motor units and reduce muscle atrophy. J Neurosci 28:12409-12418. CrossRef Medline 